\title{
68. CALCIUM CARBONATE AND ORGANIC CARBON STRATIGRAPHY OF LATE QUATERNARY LAMINATED AND HOMOGENEOUS DIATOM OOZES FROM THE GUAYMAS SLOPE, HPC SITE 480, GULF OF CALIFORNIA ${ }^{1}$
}

\author{
Joseph P. LeClaire, Deep Sea Drilling Project, Scripps Institution of Oceanography, La Jolla, California \\ and \\ Kerry R. Kelts, Eidgenössische Technische Hochschule, Geologisches Institut, Zürich, Switzerland
}

\begin{abstract}
We analyzed 580 integrated scrape-samples from HPC Site 480 for organic and carbonate carbon. Once precise dating is available, these will provide a high-resolution framework for understanding late Quaternary oceanographic and climatic fluctuations in this region. Organic carbon ranges mostly within a narrow band of 1.8 to $3.5 \% \mathrm{C}$. Calcium carbonate varies from undetectable to over $20 \%$, with an average of only about $5 \%$. Source of carbonate are mostly benthic and planktonic foraminifers, although some sections are dominated by diagenetic carbonate, shelly hash, or nannofossils. Detrital sources are low in carbonate. We divided the sequence into 17 calcium carbonate (CC) zones to separate pulses, low and median values. The CC-Zones show various second-order patterns of cyclicity, asymmetry, and events. Laminated zones have lowest uniform values, but a perfect correlation between carbonate content and homogeneous or laminated facies was not found. Maximum values tend to be located near the transition of these two sediment types, showing that accumulation of carbonate is favored during times of breakdown of stable oceanographic conditions.
\end{abstract}

\section{INTRODUCTION}

High-resolution bulk calcium carbonate profiles have proven to be useful indicators of the fluctuations in Quaternary conditions in both the Atlantic (e.g., Kellogg et al., 1976) and Pacific (e.g., Heath, et al., 1979) oceanic sequences. This is because the main sources of calcium carbonate in these areas are planktonic foraminifers and calcareous nannofossils, which are also sensitive to changes both in the surface-water regime and dissolution boundaries. The sediments of the Guaymas slope are hemipelagic, low in carbonate, and complex, because carbonate may derive from various sources (Kelts and Niemitz, this volume, Pt. 2). Dissolution effects in these areas of upwelling, high productivity, and low oxygen levels are much less predictable. The purpose of this paper is to present and discuss the results of carbon/carbonate analyses from an almost continuous series of approximately 580 samples from the 154-meter-long hydraulic piston core (HPC) 480 . The stratigraphy is summarized in Figure 1.

The HPC 480 provides a unique and valuable expanded, high-resolution record of the paleoceanography of this region of the Gulf during approximately the last 200,000 years. The sediment record will help define fluctuations on a scale of less than hundreds of years. The results of the carbon/carbonate stratigraphy are intended to serve as a guide for other types of paleoclimatic investigations, such as oxygen isotopes (Shackleton, this volume, Pt. 2), pollen analysis (Heusser, this volume, Pt. 2; Byrne, this volume, Pt. 2), or micropaleontology (Crawford and Schrader, this volume, Pt. 2).

${ }^{1}$ Curray, J. R., Moore, D. G., et al., Init. Repts. DSDP, 64: Washington (U.S. Govt. Printing Office).

\section{METHODS}

In order to obtain an average, integrated value for small intervals, and to protect the valuable rhythmic laminations and other sedimentary structures, about $3 \mathrm{~cm}^{3}$ of sediment was removed from a 10 to $20-\mathrm{cm}$ interval of the core surface of the working half surface by gently shaving with a straight razor. Scraping was done parallel to the laminae after first trimming the core surfaces of any contamination from wire-line splitting. The process was repeated the length of the hole, providing a continuous series of about 980 samples. The $20-\mathrm{cm}$ intervals are from homogeneous zones, on the assumption that bioturbation has previously reworked the carbonate signal. The intervals were described and boundaries were carefully chosen to correspond with the same intervals used for isotope stratigraphy and pollen stratigraphy (Shackleton, this volume, Pt. 2; Heusser, this volume, Pt. 2; see description in Kelts and Niemitz, this volume, Pt. 2). The highly disturbed core-catcher samples are not plotted, but the results are listed in Appendix II (Simoneit and Bode, this volume, Pt. 2).

The samples were analyzed at the DSDP sediment laboratory using a Leco WR-12 70-second carbon analyzer. The method for obtaining acid-soluble (calcium carbonate) and -insoluble (organic carbon) values respectively is discussed in detail by Boyce and Bode (1972). A brief outline is given here:

Each sample was dried for 24 hours at 105 to $110^{\circ} \mathrm{C}$, ground to a fine homogeneous powder, and then re-dried. The samples were then divided into two splits, and each was weighed to \pm 0.003 grams. The first split was analyzed directly with the Leco carbon analyzer, and the value was reported directly as percent by weight of total carbon. The second split was acidified with $10 \%$ hydrochloric acid, and analyzed. The value is reported as weight percent organic carbon. The theoretical percentages of calcium carbonate in the samples were calculated as: (\% total C - \% "organic" carbon) $\times 8.33=\%$ calcium carbonate. It should be noted here that all the carbonate in the sample is not necessarily calcium carbonate, but may include some scattered dolomite-or, for example, the dolomitic bed at 100.75 meters (Kelts and McKenzie, this volume, Pt. 2). The Leco carbon analyzer was calibrated with Leco standard iron rings. The precision of the Leco with a single operator over a short period of time as reported by Boyce and Bode (1972) is:

\footnotetext{
Total carbon

$(1.2-12 \%)= \pm 0.2 \%$ (absolute variation)

$(0-1.2 \%)= \pm 0.04 \%$ (absolute variation)
} 


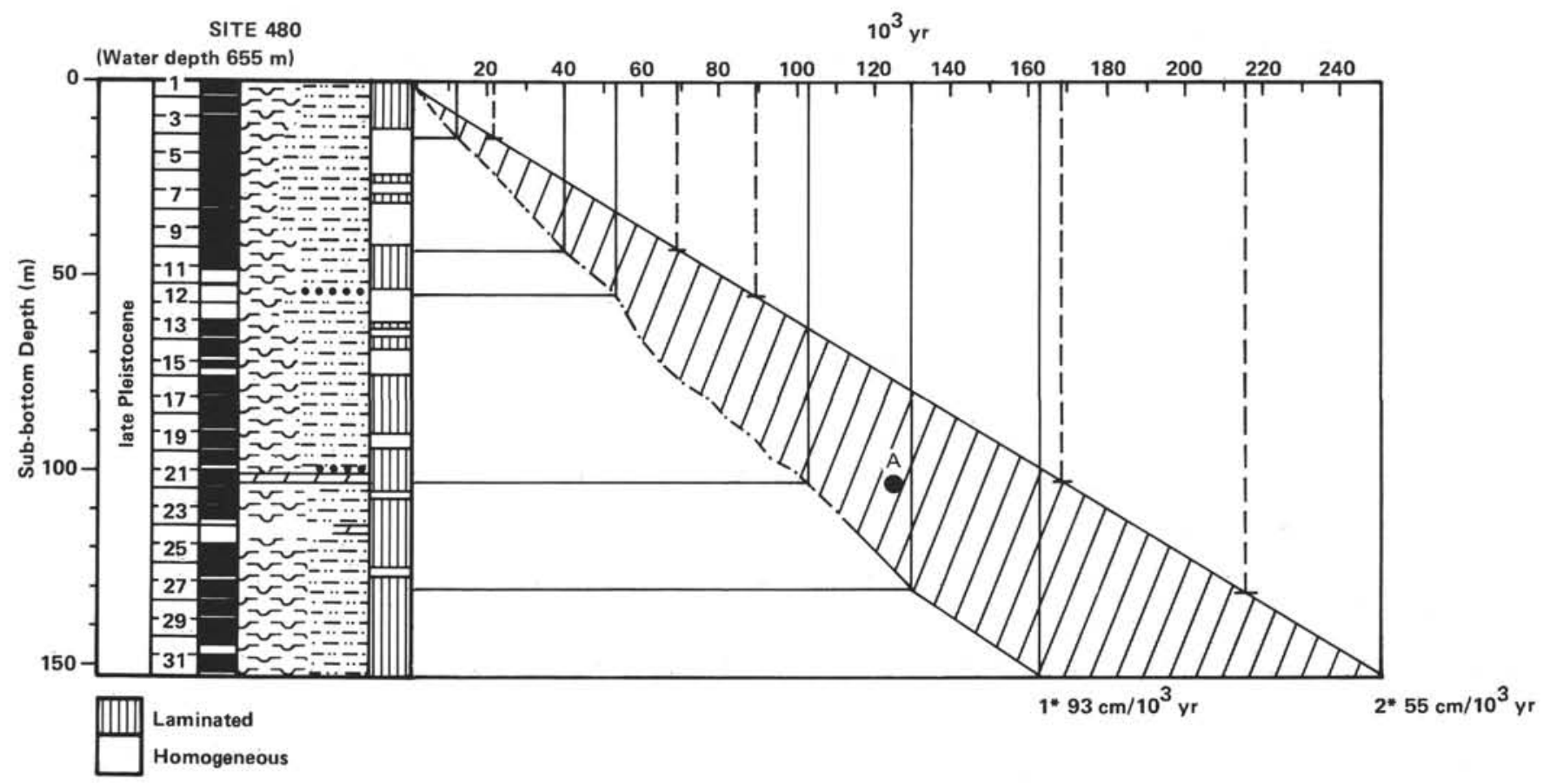

Figure 1. General stratigraphy of HPC Site 480 , with present best-estimate ranges of accumulation rates (shaded zone). $1^{*}$ is from Soutar et al. (this volume, Pt. 2), based on varve counts. $2 *$ is from Schrader (this volume, Pt. 2), based on the occurrence of Nitzschia fossilis in Core $480-29$ and correlation with Site 479. Note that homogeneous zones have slower accumulation rates than average. (A denotes the early part of interglacial stage 5e; see text for discussion.)

\author{
Organic carbon $= \pm 0.04 \%$ (absolute variation) \\ Calcium carbonate \\ $(10-100 \%)= \pm 2.0 \%$ (absolute variation) \\ $(0-10 \%)= \pm 0.6 \%$ (absolute variation)
}

\section{RESULTS}

The analytical results are listed in the accompanying Appendix and plotted against the lithologic column in Figure 2. These values range from 0 to $38 \% \mathrm{CaCO}_{3}, 1.3$ to $3.6 \%$ organic $C$, and 1.9 to $6.5 \%$ total $C$. The sediments are rich in organic carbon, which shows faint cyclic patterns ranging from 2 to $3.2 \%$ on a 5 - to 10 -meter-scale, with about $1 \%$ scatter. There is a slight gradient of increasing total carbon up-section which is a reflection of generally greater carbonate percentages in the upper half of the hole. A look at the plot (Fig. 2) shows a mixed pattern for calcium carbonate, with low base-line values overprinted by shorter excursions. Although there is a tendency for lowest values to correlate with laminated-sediment zones, there is not such a clear correlation of higher values with homogeneous zones. Commonly, maximums occur at the transition of homogeneous laminated zones. Sudden jumps in calcium carbonate were caused by benthic foraminifers, with contributions from nannofossils or diagenetic carbonates. In order to systematically analyze these features, we subdivided the 152 -meter sediment column into $17 \mathrm{car}$ bonate (CC) zones which separate characteristic parts of the data sets into groups of low or intermediate values, or pulses (see Table 1). A pulse was defined by a shift of $\mathrm{CaCO}_{3}$ over 3 sections, and may comprise several events, i.e., short-period jumps. Pulses and events may be caused by various mechanisms. Because of the compression of so many data points into this scale, many of the secondary and tertiary trends are masked. We have therefore selected certain representative sections, which are enlarged and matched with the sediment lithology from core-barrel descriptions (Figs. 3 to 9). (Each of the data points relates to a specific sedimentologic cause, and therefore no mathematical smoothing has been applied to the raw data.) The analysis results are stored on tape at the Deep Sea Drilling Project Information Handling Group, and are available in plots of variable scale.

\section{DISCUSSION}

In order to interpret the carbon/carbonate stratigraphy in terms of fluctuating paleoceanographic circulation or climatic patterns, the results must be placed in a relative time frame. The age of the oldest sediment recovered at the bottom of HPC Site 480 , and therefore the sedimentation rate, is not known with certainty. Interpretations therefore remain preliminary. Discontinuous occurrences of appropriate benthic foraminifers hampered ${ }^{18} \mathrm{O}$ stratigraphy (Shackleton and Hall, this volume, Pt. 2). Soutar et al. (this volume, Pt. 2) used varve counts and adjusted for diatom content and bulk density in homogeneous zones to estimate minimum accumulation rates to Core $480-21$, giving an extrapolated basal age of at least $165 \times 10^{3} \mathrm{yr}$ or $0.93 \mathrm{~m} / 10^{3} \mathrm{yr}$ (Fig. 1). The occurrence of Nitzschia fossilis in Core 29 suggests an average rate of $0.55 \mathrm{~m} / 10^{3} \mathrm{yr}$, or a basal age nearer $250 \times 10^{3} \mathrm{yr}$ (Schrader, this volume, Pt. 2). The rate determined for the upper 150 meters of rotary- 


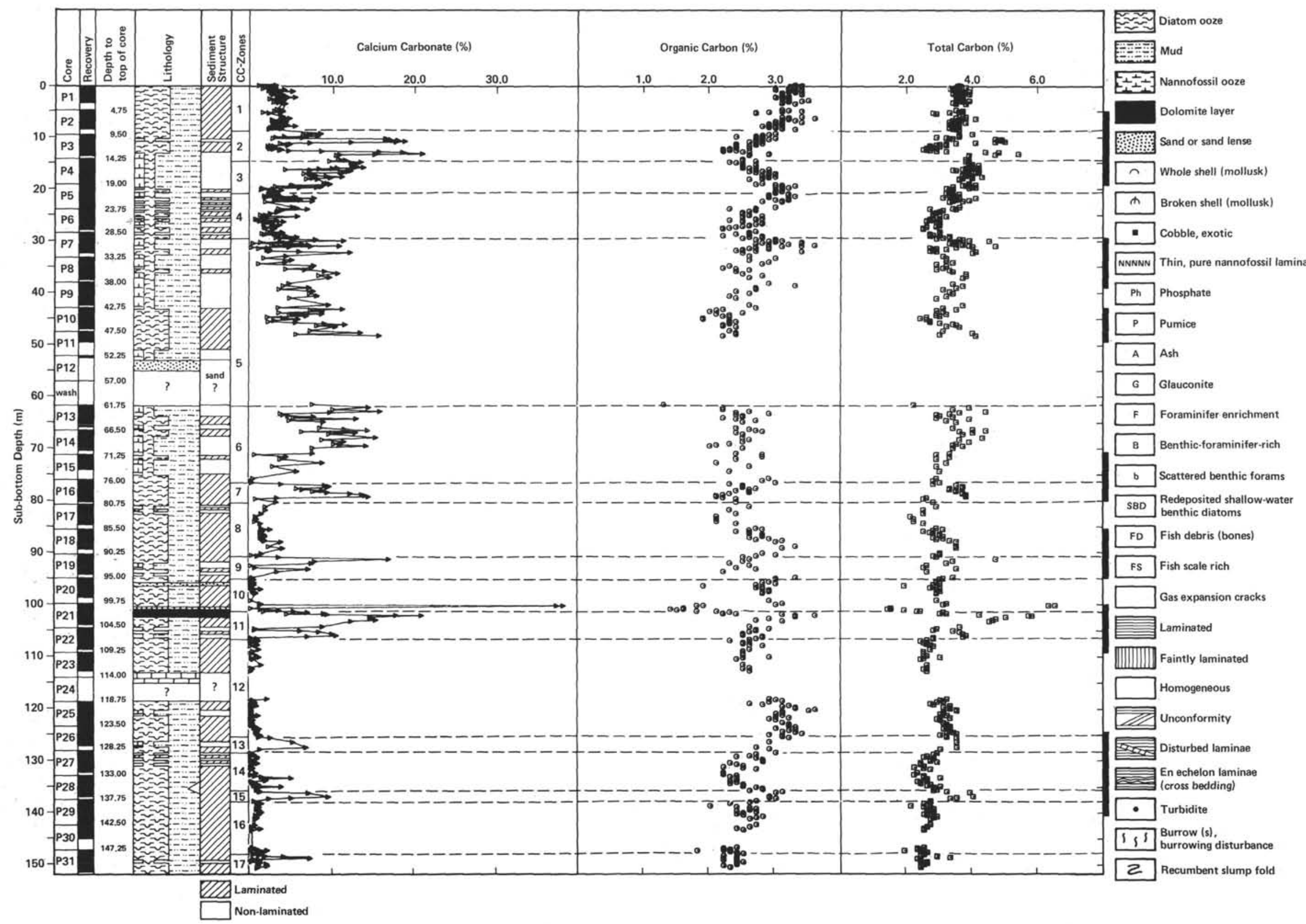

Figure 2. Core lithology and cumulative plots of all results from the Leco analysis. Note the position of 17 carbonate zones defined in this paper. Bars along the right margin indicate the position of detailed sections shown in following figures. 
Table 1. Subdivisions of the sediment column.

\begin{tabular}{|c|c|c|c|c|}
\hline $\begin{array}{l}\text { Carbonate } \\
\text { Zone }\end{array}$ & $\begin{array}{l}\text { Sub-bottom } \\
\text { Depth } \\
\text { (m) }\end{array}$ & $\begin{array}{l}\text { Characteristics/Events } \\
\text { Carbonate Trends }\end{array}$ & $\begin{array}{l}\text { Organic-Carbon } \\
\text { Trend }\end{array}$ & $\begin{array}{l}\text { Estimated } \\
\mathrm{Age}^{\mathrm{a}} \\
10^{3} \mathrm{yr}\end{array}$ \\
\hline $\mathrm{CC}-1$ & $0.00-9.50$ & Low $(2-5 \%)$, uniform, scattered benthic foraminifers & High $(3 \%)$ & $\begin{array}{c}\text { Holocene } \\
0-10\end{array}$ \\
\hline CC-2 & $9.50-14.85$ & $\begin{array}{l}\text { Laminated and non-laminated zones; two well-defined peaks ( } 20.7 \text { and } 18.7 \% \text { ) } \\
\text { and a third moderate pulse }(7 \% \text { ) associated with transitional boundaries (LAM } \\
\text { to HOM); both peaks in non-laminated, silty, nannofossil-bearing, muddy, } \\
\text { diatomaceous oozes, with benthic foraminifers (Fig. 3) }\end{array}$ & $\begin{array}{l}\text { Lower }(2 \%) \text {; } \\
\text { increases up-section }\end{array}$ & $\begin{array}{l}\text { Late glacial } \\
\qquad 10-14\end{array}$ \\
\hline $\mathrm{CC}-3$ & $14.85-20.10$ & $\begin{array}{l}\text { Non-laminated section; irregular but generally increasing trend from bottom to } \\
\text { top of zone (3-14\%), accompanied by modest pulses (Fig. } 3 \text { ); these minor peaks } \\
\text { are sharp, but rise only } 4 \text { to } 6 \% \text { from the increasing base-line value; homogeneous } \\
\text { muds with some shell fragments and fish debris; benthic foraminifers; nannofossils; } \\
\text { diatomaceous mud; mottled }\end{array}$ & $\begin{array}{l}\text { Decreases slightly } \\
\text { up-section }(3-2 \%)\end{array}$ & $14-20$ \\
\hline $\mathrm{CC}-4$ & $20.10-29.70$ & $\begin{array}{l}\text { Low, erratic; values from } 0.5 \text { to } 7.4 \% \text {. Laminated and homogeneous zones } \\
\text { alternate on a small scale }\end{array}$ & Mixed $(2.5 \%)$ & $20-30$ \\
\hline CC-5 & $\begin{array}{l}29.80-48.66 \\
\text { (gap to } \\
\text { 61.99) }\end{array}$ & $\begin{array}{l}\text { Intermediate }(9 \%) \text {; very erratic }(0-16 \%) \text { broad zone; base-line values about } 3 \\
\text { to } 4 \%) \text {. Alternating laminated and non-laminated zones; generally but not } \\
\text { exclusively higher in non-laminated (Fig. } 4) \text {; low and intermediate episodes continue } \\
\text { in non-laminated sections; small-scale cyclic patterns (e.g., Fig. 5) overprinted on in- } \\
\text { creasing or decreasing patterns; variable benthic foraminifers, fish debris }\end{array}$ & $\begin{array}{l}\text { Intermediate, mixed } \\
(2.3 \%)\end{array}$ & $30-50$ \\
\hline $\mathrm{CC}-6$ & $61.99-75.50$ & $\begin{array}{l}\text { Similar to above but separated by a } 12 \text {-meter coring gap; intermediate, erratic } \\
(0-15.7 \%) \text {; upward overall increase in the base-line from } 0 \text { to about } 5 \text { to } 6 \% \text {; } \\
\text { four alternations homogeneous to laminated; scattered broken shells, some fish } \\
\text { debris; asymmetric patterns; lowest values commonly in laminated zones; highest ir- } \\
\text { regular }\end{array}$ & $\begin{array}{l}\text { Intermediate } \\
(2.6 \%)\end{array}$ & $50-65$ \\
\hline $\mathrm{CC}-7$ & $75.50-80.10$ & $\begin{array}{l}\text { Pulse with two sharp asymmetric peaks bracketed by very low values }(<1 \%) \\
\text { (Fig. 6); from the base }(<1 \%) \text { there is a sharp rise to } 14.3 \% \text {, accompanied by } \\
\text { the appearance of some pure nannofossil laminae; gradual decrease with a minor } \\
\text { pulse at } 77.70 \mathrm{~m} \text {; sediment laminated, but has some large irregular patches of } \\
\text { homogeneous muds; scattered fish debris, phosphate, rare foraminifers }\end{array}$ & $\begin{array}{l}\text { Slight upward trend } \\
(2.0-3.0 \%)\end{array}$ & $65-75$ \\
\hline CC-8 & $80.10-91.15$ & $\begin{array}{l}\text { Low }(0-3.6 \%) \text {, uniform, laminated; thick diatom ooze laminae in Sections } 18-1 \\
\text { and } 2 \text { (Fig. 7) }\end{array}$ & $\begin{array}{l}\text { Decreasing upward } \\
(3.2-2 \%)\end{array}$ & $75-90$ \\
\hline CC-9 & $91.15-94.15$ & $\begin{array}{l}\text { Two pulses ( } 7 \text { and } 16.8 \% \text { ) associated with transition from homogeneous to } \\
\text { laminated zones (Fig. } 7 \text { ); sharp peaks with gradual decline; skewed up-hole }\end{array}$ & $\begin{array}{l}\text { Intermediate } \\
(2.5 \%)\end{array}$ & $90-95$ \\
\hline CC-10 & $94.15-101.85$ & $\begin{array}{l}\text { Very low }(0-1.2 \%) \text {, uniform, laminated, but including one grayish-yellow, } \\
\text { hard dolomitic bed }(37 \%) \text { and multiple, thin, gray, graded clastic beds at the base of } \\
\text { the zone (Fig. } 8) \text {; silty and sandy clastic layers have very low carbonate values } \\
(0-3 \%)\end{array}$ & Low (to $1.2 \%$ ) & $90-103$ \\
\hline CC-11 & $101.85-107.00$ & $\begin{array}{l}\text { Two pulses, transitional to non-laminated facies; maximum values of } 10.4 \text { and } \\
20.8 \% \text { (upper) (Fig. } 8 \text { ); each peak in non-laminated facies is bracketed by near-zero } \\
\text { levels; upper pulse ends in the first graded clastic layer }\end{array}$ & $\begin{array}{l}\text { Intermediate to } \\
\text { highest }(3.5 \%) \\
\text { near top }\end{array}$ & $103-110$ \\
\hline CC-12 & $\begin{array}{l}107.00-126.20 \\
\text { (no recovery } \\
113.45-118.85 \text { ) }\end{array}$ & $\begin{array}{l}\text { Low }(0-2 \%) \text {, uniform, laminated (Figs. } 8 \text { and 9) (small homogeneous interval } \\
118.85-121.25 \mathrm{~m} \text { ) }\end{array}$ & $\begin{array}{l}\text { High in lower part } \\
\text { to intermediate } \\
\text { above }\end{array}$ & $110-125$ \\
\hline CC-13 & $126.20-128.57$ & $\begin{array}{l}\text { Pulse (0-6.7\%); asymmetric, homogeneous zone, with alternations (Fig. 9); } \\
\text { pulse has an abrupt base and gradual decline; sediment with scattered mottles, } \\
\text { phosphate, fish scales, and some redeposited shallow-water benthic diatoms }\end{array}$ & $\begin{array}{l}\text { Intermediate } \\
(2.7 \%)\end{array}$ & $125-127$ \\
\hline CC-14 & $128.57-136.80$ & $\begin{array}{l}\text { Low }(0-1.5 \%) \text {; uniform with minor events; laminated peaks at } 135.80 \mathrm{~m}(3.7 \%) \\
\text { and } 134.10(4.9 \%) \text { (Fig. } 9 \text { ) associated with a few thin, white laminae of pure, } \\
\text { almost monospecific nannofossil ooze; a few friable pumice pieces at } 134.15 \mathrm{~m}\end{array}$ & Low $(2.2 \%)$ & $127-134$ \\
\hline CC-15 & $136.80-138.61$ & $\begin{array}{l}\text { Pulse }(9.4 \%) \text {; crosses a thin, homogeneous zone (Fig. 9); gradual increase and } \\
\text { decrease in laminated facies; bioturbation, numerous benthic foraminifers }\end{array}$ & High $(3.0 \%)$ & $134-135$ \\
\hline CC-16 & $138.61-149.15$ & Low $(0-2.0 \%)$, uniform, laminated & $\begin{array}{l}\text { Intermediate } \\
(2.5 \%)\end{array}$ & $135-159$ \\
\hline $\mathrm{CC}-17$ & $149.15-151.35$ & $\begin{array}{l}\text { Pulse event, sharp maxima }(149.75 \mathrm{~m}) \text { to } 7.2 \% \text {, gradual convex decline; above } \\
\text { and below, low; sediment laminated to faintly laminated, scattered fish debris; pulse } \\
\text { with a short homogeneous zone }\end{array}$ & Lower $(2.2 \%)$ & $159-163$ \\
\hline
\end{tabular}

${ }^{\mathrm{a}}$ Based on Figure 1, derived from interpolated varve counts from Soutar et al. (this volume, Pt. 2).

cored sister Site 479 is in good agreement with this. This divergence is significant, and constrains the assignment of sedimentologic pulses and events to a specific climatic stage. On the basis of sedimentology, one might speculate that, within the given framework, the siltsand and diagenetic carbonate in Cores $480-20$ and 21 $(101.7 \mathrm{~m})$ are associated with the early part of interglacial stage 5e (Shackleton and Opdyke, 1973), or an age of about $125 \times 10^{3} \mathrm{yr}$ (Fig. 1, point A). The site depth of 655 meters is beyond the range of sea-level drop, but one possibility is that sandy layers might represent ris- ing-sea-level cannibalizing of shoreline clastics which then spill over the slope. We have chosen the estimates $\left(0.93 \mathrm{~m} / 10^{3} \mathrm{yr}\right)$ of Soutar et al. (this volume) in order to give some relative control to the length of time represented by each carbonate zone. The likelihood of leaving out years is greater than overcounting, so that these ranges will give a minimum time, and an order of magnitude. Individual samples represent about 100 to 200 years per sample.

We have grouped the carbonate zones in Table 1 with a brief outline of characteristic patterns. We discard the 


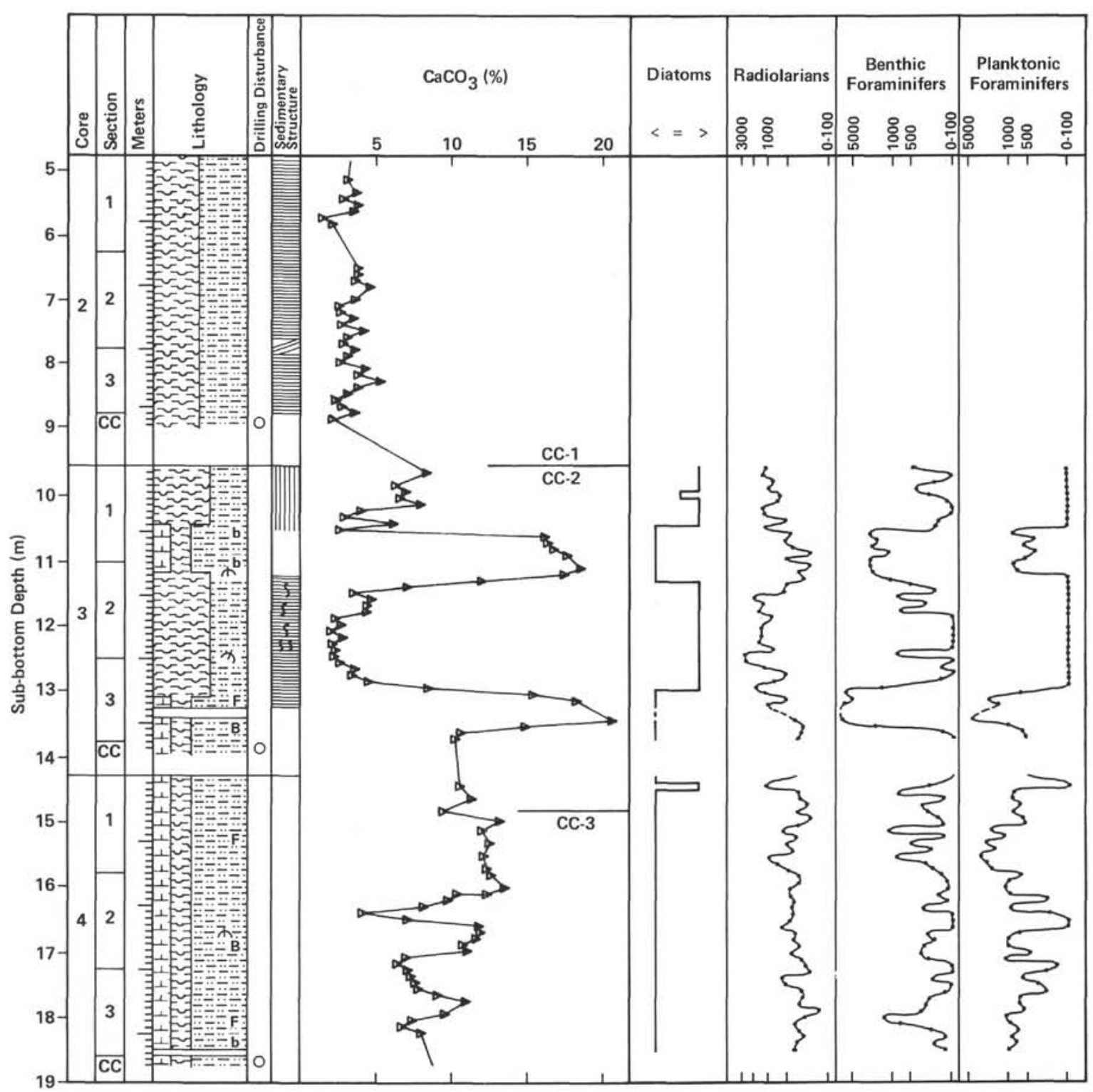

Figure 3. Detail of carbonate pattern across the Pleistocene/Holocene boundary. Correlated with coarse-fraction counts (Crawford and Schrader, this volume, Pt. 2).

possibility that the homogeneous sediments may be turbidites, because there is no supporting sedimentologic evidence, such as grading of carbonate components. Schrader (this volume, Pt. 2) has shown that upwelling signals are present in the homogeneous zone, and organic carbon is uniformly distributed. Therefore, the homogeneous versus laminated facies are the result of minor shifts in the bottom-water oxygen budget at this site. Changes are the result of oxygen-minimum-layer shifts arising from glacially controlled sea level or from productivity fluctuations.

If the non-laminated zones are produced by infaunal bioturbation, one might expect that organic carbon would be significantly lower relative to laminated zones. This is not shown by the curves; instead, they show similar concentrations in both types. This would support Schrader's view (this volume, Pt. 2) that bioturbation is incomplete, only preventing laminae from forming. Simoneit has shown (this volume, Pt. 2) that both the non-laminated and laminated zones show similar microbial sources for organics. The non-laminated zones, however, have higher plant wax detritus relative to the microbial. He interprets these results as either a result of higher input of terrigenous minerals but with constant terrigenous lipid influx during the non-laminated intervals, or a result of a partially oxic environment accompanying the lower sedimentation rate zones which slightly concentrates the refractive waxes. This suggests that laminated sections represent higher sedimentation rates due to increased algal productivity.

\section{ORIGIN OF SIGNALS}

The shape of the calcium carbonate curve with depth is dependent on (1) variations in sources, including type and accumulation rates for planktonic tests, benthic fauna, and shallow-water or land-derived carbonate influx, (2) carbonate dissolution at the sediment/water 


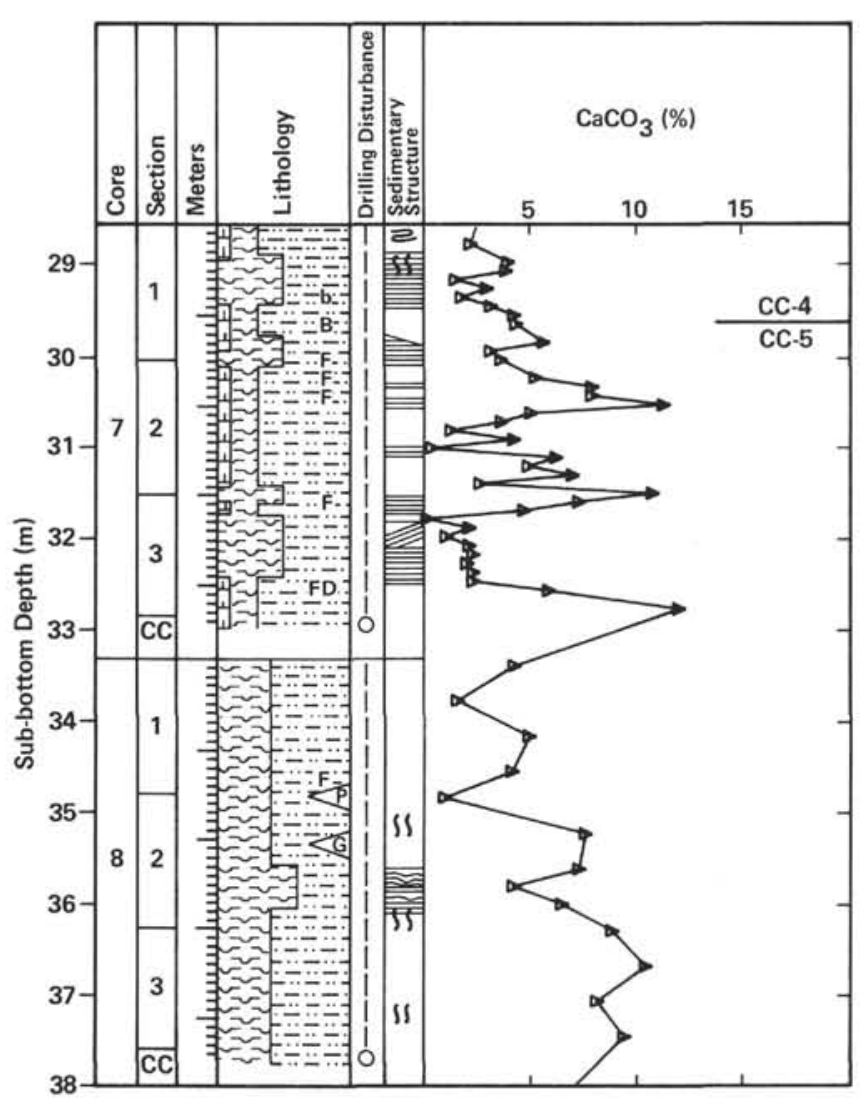

Figure 4. Erratic pattern of median values in carbonate zone 5 from foraminifer signals.

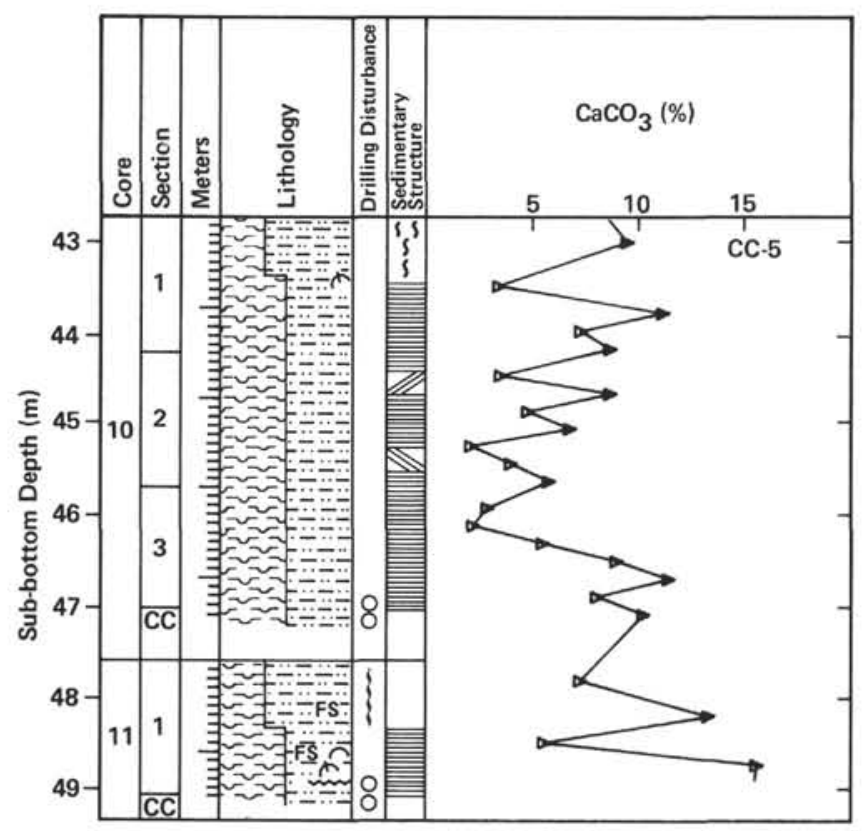

Figure 5. Cyclic pattern in laminated facies of CC-5.

interface, or post-depositional changes, including precipitation, and (3) dilution of biogenic silica or terrigenous silicoclastics. The Guaymas slope is part of a restricted, unique environment, and the stresses exerted on the system by glacial/interglacial fluctuations are not

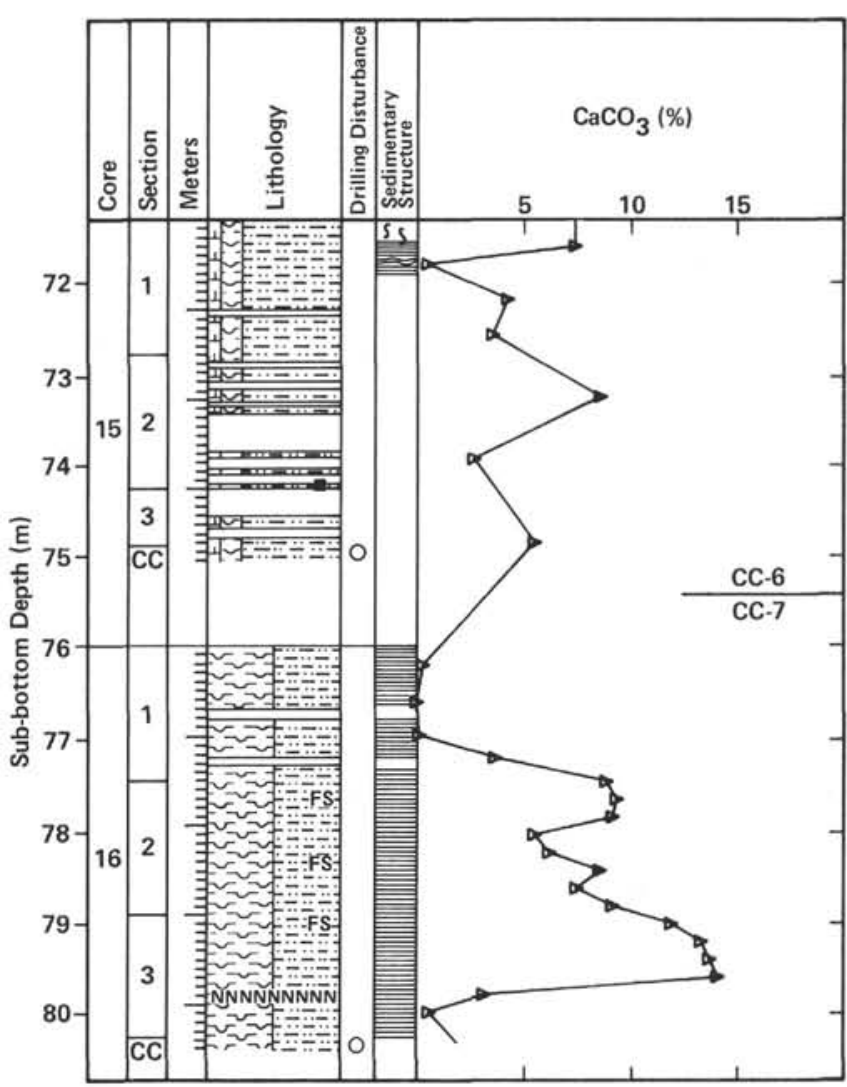

Figure 6. Pulse and decay from nannofossil blooms associated with laminated facies of CC-7.

likely to exact the same responses on carbonate stratigraphy as in the open ocean. Changes in nutrient budget, upwelling, ocean currents, and productivity are not clearly predictable.

The curve in Figure 2 represents abundances of foraminifers as shown by the positive correlation of foraminifer counts (Fig. 3) with carbonate peaks (from Crawford and Schrader, this volume, Pt. 2), at least in the upper half of the hole. Deeper, for example in CC-7 or CC-14 (Figs. 6 and 9), pulses in carbonate seem to correlate with zones having thin laminae of pure, monospecific nannofossil ooze and abundant fish scales. These must represent times of unusual or stressed upwelling conditions that are possibly accompanied by lower surface salinities.

Terrigenous sands and silt layers in Core 20 are almost devoid of calcium carbonate, suggesting that detrital carbonate is not a significant factor (see CC-10; Fig. 8 ). On the other hand, the presence of a hard, thin bed at 100.75 meters (CC-10, Fig. 8), which has the highest carbonate content $(37 \%)$ of the analyzed samples, poses a problem. X-ray-diffraction and stable-isotope analyses show it to consist of a calcium-rich dolomite cement which has formed diagenetically in the high-alkalinity, anoxic sediment (see Kelts and McKenzie, this volume, Pt. 2). At this stage, we cannot yet eliminate the possibility that some other carbonate pulses also have a component of diagenetic carbonate. Some dark streaks also contain phosphatic pellets. 


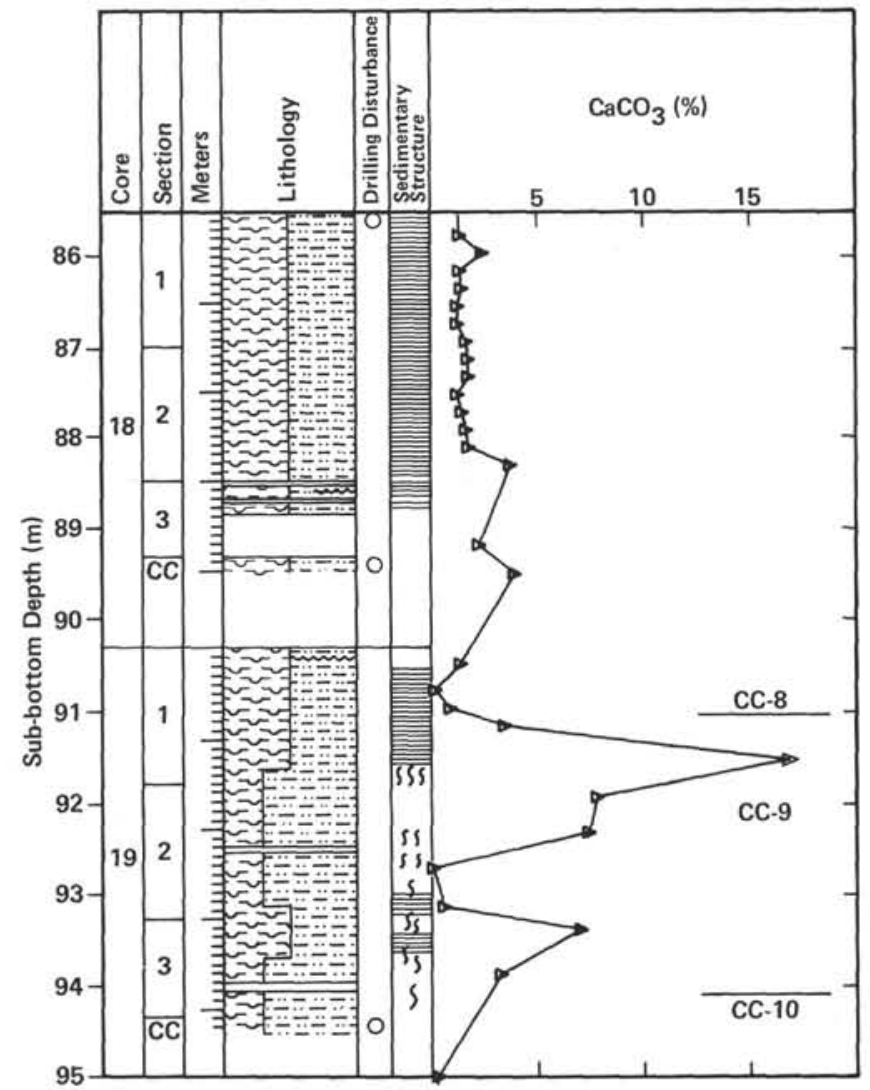

Figure 7. Two events in CC-9 across transitional boundaries.

\section{DISSOLUTION EFFECTS}

At Site 480 , the lower water column is moderately stable on a seasonal basis (Roden, 1964). High productivity of diatoms (and dinoflagellates) leads to decreased amounts of oxygen in the bottom waters because of the corresponding increase in falling particulate organics. However, higher diatom productivity would not necessarily lead to more foraminifers or calcareous nannofossils. On the contrary, diatoms can mask other constituents. Because diatoms are more efficient scavengers for nutrients and have a shorter growth period, they tend to compete better than calcareous plankton in nutrient-rich environments. This explains in part why the laminated zones tend to be very low in carbonate. The level of bottom-water oxygen might also be below the tolerance level for even sturdy benthic foraminifers such as Bolivina.

Dissolution is partly dependent on the rate of burial. If the sediments are highly reducing, then a rapid increase in alkalinity may actually lead to the preservation of carbonate. Most of the dissolution must take place at the ocean-water/sediment interface (Berger, 1976). If the overlying water is completely anoxic, then anaerobic sulfate reduction may tend to preserve carbonate (Dunbar and Berger, 1981). On the other hand, if even traces of oxygen persist, then the bottom waters can become exceedingly corrosive (Berner, 1971). Therefore, very slight shifts of the oxygen budget can have considerable and slightly unpredictable effects on the carbonate pres-

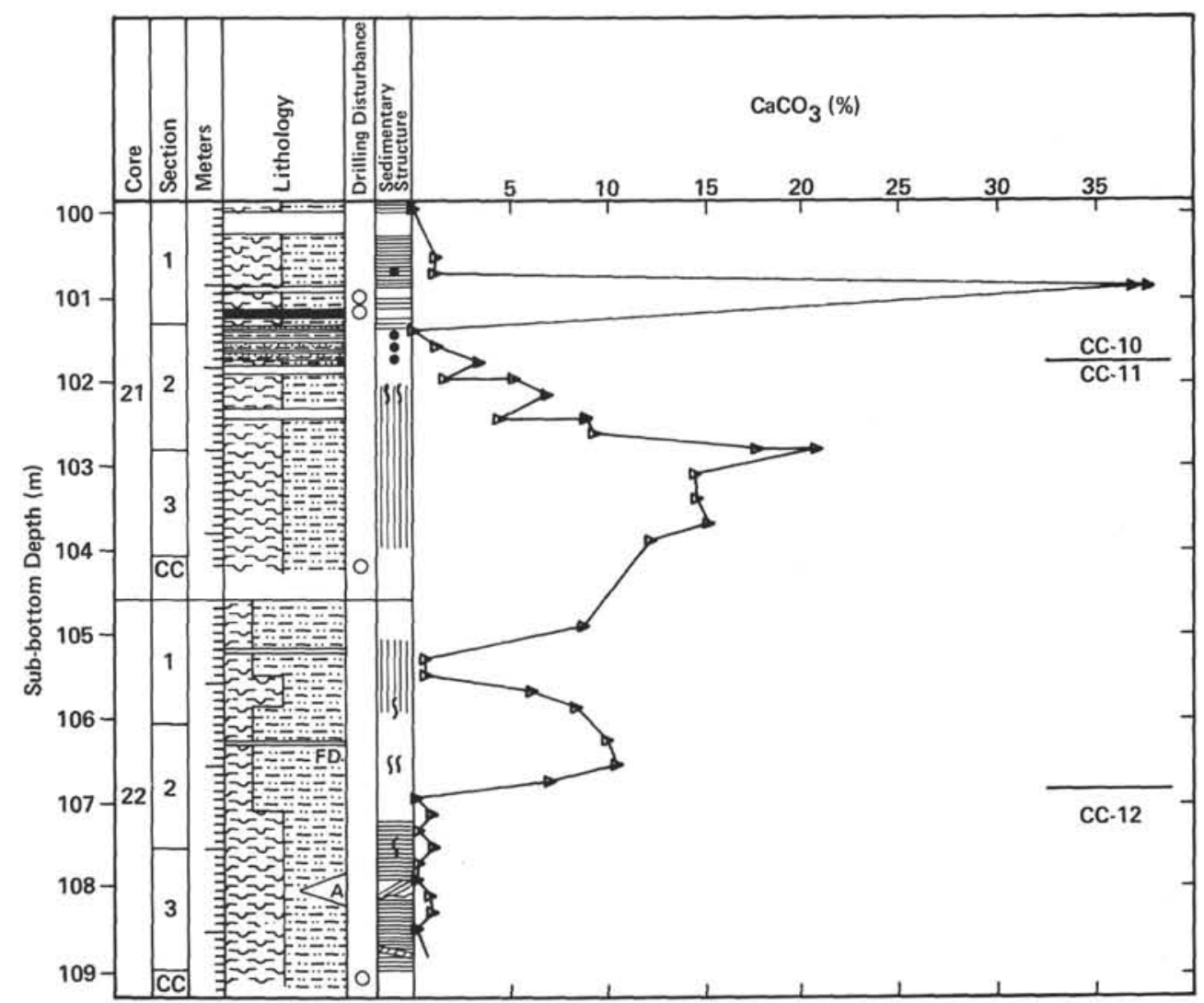

Figure 8. Maximum carbonate value in dolomitic layer at 101.05 to $101.17 \mathrm{~cm}$. Low values in rhythmic turbidites. Pulse/events in the homogeneous facies of $\mathrm{CC}-11$ may have diagenetic carbonate component. 


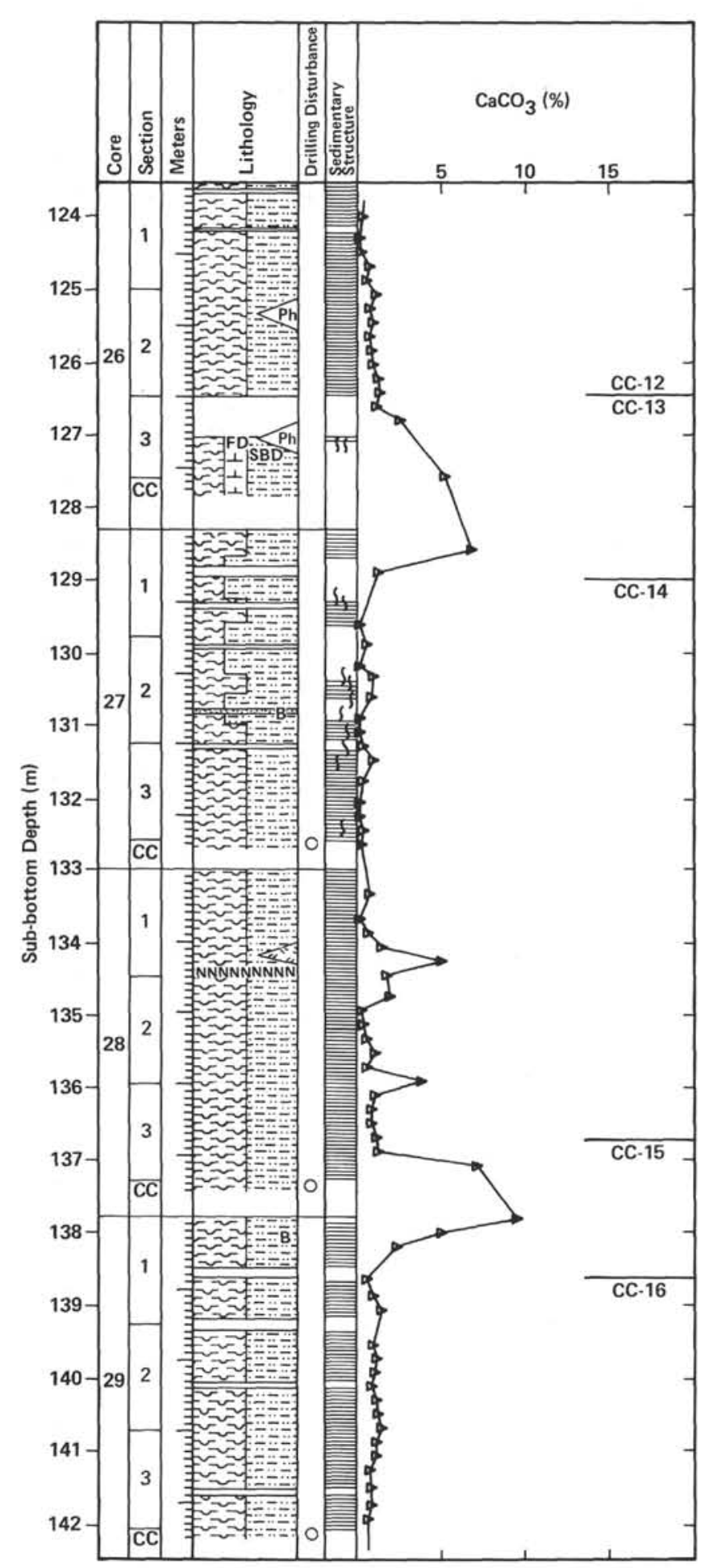

Figure 9. Lower part of hole with very low background carbonate content in laminated facies and short-period, asymmetric pulses.

ervation in the sediment. The Guaymas basin and slope today is close to anoxic, but has traces of $\mathrm{O}_{2}$ (Roden, 1964). In the past, it could have been briefly anoxic. In fact, times of mass overturn, or replacement of one water mass by another, might favor carbonate preservation. Crawford and Schrader (this volume, Pt. 2) indicate a correlation between planktonic- and benthic- foraminifer abundance, which suggests that the processes affect both surface and bottom conditions.

\section{PLEISTOCENE/HOLOCENE BOUNDARY}

The transition from the outgoing late glacial and the Holocene occurs with CC-Zone 2, within Core 480-3. It is marked by the upward, abrupt shift to laminated facies. The transition at 13 meters is accompanied by an increase in carbonate from both benthic and planktonic foraminifers (Fig. 3). A second event at 11 meters straddles another transition boundary and shows abundant nannofossils. It may represent a short-term climatic shift such as the 11,000-year-old Two Creeks or Allerod periods. The short period variations in the carbonate content below the boundary (Core 480-4) clearly indicate that the homogeneous zones also record patterns with high resolution.

Cyclic Patterns. Several of the carbonate zones show secondary cyclic patterns overprinted on increasing or decreasing first-order trends. For example, in Figure 5, this is displayed in an interval of 3.5 meters from 46.5 to 43 meters sub-bottom, which show a 100 - to 200 -year duration. These possibly document gradual changes in upwelling conditions through a laminated zone, if dissolution conditions are uniform. Other examples are also illustrated in Figure 3 at 11 meters and 13 meters; Figure 8 at 106 to 107 meters; and Figure 9 at 127 to 129 meters and 137 to 138 meters.

Asymmetry. A common feature of the carbonate record is the abrupt initiation and slower decay of several pulses or events. This is illustrated by Figure 6, although in this case the higher carbonate content of this laminated zone seems qualitatively to be derived from an abundance of nannofossil-rich layers.

Diagenetic Carbonate. The dolomitic layer recovered at 101.05 to 101.17 meters is not directly associated with high carbonate zones (Fig. 8). Just below, there is a series of 19 thin, graded silts with low organic-carbon and carbonate content. Below these, carbonate content rises, partly because of disseminated dolomite rhombs and benthic foraminifers. The singularity of this sequence in Core 480-21 can be explained if it is associated with the climatic optimum attained during the early part of the penultimate interglacial $5 \mathrm{e}$, because that represents one fairly short interval during the last 400,000 years.

In the lower parts of the core, laminated zones with very low carbonate content are dominant (Fig. 9), punctuated by short $\mathrm{CC}$ events. These probably reflect morestable primary conditions of upwelling rather than a long-term diagenetic dissolution effect.

\section{CONCLUSIONS}

The carbon/carbonate stratigraphy of HPC Site 480 provides important constraints on the interpretation of paleoclimate or paleoceanography in the Guaymas Slope region. The organic carbon content is uniformly high $(1.8-3.5 \%)$, with a gradual decrease down-hole. Fluctuations are modest, slightly less organic carbon being associated with carbonate or clastic peaks. The carbonate content, however, shows several complex but 
characteristic patterns. We have divided the sequence into 17 calcium carbonate (CC) zones based on short intervals of either low, median, or pulsed values. We interpret the pulses to represent relatively rapid, shortterm perturbations in prevailing upwelling or oceanographic conditions. These are probably indirectly linked to climate variations. The record might indicate for example that incursions of the California Current were quick-on the order of hundreds of years. Typically a pulse reaches prime within a few hundred years and decays over a few thousand. Pulses are most commonly associated with foraminifer abundance, but other causes, such as high nannofossil production or diagenetic carbonate, are also important. More stratigraphic information is needed to determine whether primary productivity and bottom-water oxygen exert more control on the pattern than dissolution effects. There is a general trend of low carbonate content in the laminated facies, but exceptions abound. Peaks in the carbonate signal commonly fall in the transition zone between laminated and homogeneous diatomaceous mud facies. This also underlines evidence of a fairly rapid rate of replacement of water masses.

Numerous problems remain. The location of the dolomitic layer is puzzling: zones containing well-preserved foraminifers exist above and below. Detailed mineralogy on bulk and carbonate components is needed for each of the samples, as well as estimates of dissolution effects. The lack of a precise dating basis limits, for the moment, a clear interpretation of the carbon-carbonate stratigraphy.

\section{ACKNOWLEDGMENTS}

We are pleased to acknowledge the Deep Sea Drilling Project for providing laboratory facilities and support for this project. Linda Garifal helped smooth sampling problems. We thank Lola Boyce and Doris Rüegg for typing the manuscript, and Kathy Sanderson for preparing illustrations. The analyses were completed (by J. L.) as part of a UCSD senior research project while he was employed at DSDP. We thank Jeff Niemitz and Hans Thierstein for thoughtful reviews.

\section{REFERENCES}

Berger, W. H., 1976. Biogenous, deep sea sediments: production, preservation and interpretation. In Riley, J. P., and Chester, R. (Eds.), Chemical Oceanography (Vol. 5): New York (Academic Press), 266-388.

Berner, R. A., 1971. Principles of Chemical Sedimentology: New York (McGraw-Hill).

Boyce, R. E., and Bode, G. W., 1972. Carbon and carbonate analysis, Leg 9. In Hays, J. D., et al., Init. Repts. DSDP, 9: Washington (U.S. Govt. Printing Office), 797-816.

Dunbar, R. B., and Berger, W. H., 1981. Fecal pellet flux to modern bottom sediment of Santa Barbara Basin (California), based on sediment trapping. Geol. Soc. Am. Bull., 92:212-218.

Heath, G. R., Moore, T. C., and Dauphin, J. P., 1979. Organic carbon in deep sea sediments. In Andersen, N. R., and Malahoff, A. (Eds.), The Fate of Fossil Fuel $\mathrm{CO}_{2}$ in the Ocean: New York (Plenum Press), pp. 605-625.

Kellogg, T. B., 1976. Late Quaternary climatic changes: evidence from deep sea cores of Norwegian and Greenland Seas. Geol. Soc. Am. Mem., 145.

Roden, G. I., 1964. Oceanographic aspects of the Gulf of California. In van Andel, Tj., and Shor, G. G. (Eds.), Marine Geology of the Gulf of California: Am. Assoc. Pet. Geol. Mem., 3:59-75.

Shackleton, N. J., and Opdyke, N. D., 1973. Oxygen isotope and paleomagnetic stratigraphy of Equatorial Pacific Core V28-238: oxygen isotope temperature and ice volumes on a $10^{5}$ and $10^{6}$ year scale. Quat. Res., 3:39-55.
APPENDIX

Data Tables for Leco WR-12 Carbon-carbonate Analyses of Interval Scrape Samples from Diatomaceous Oozes at

Site $\mathbf{4 8 0}$

\begin{tabular}{|c|c|c|c|c|}
\hline $\begin{array}{c}\text { Sample } \\
\text { (level in } \mathrm{cm} \text { ) }\end{array}$ & $\begin{array}{l}\text { Sub-bottom } \\
\text { Depth } \\
\text { (m) }\end{array}$ & $\begin{array}{c}\text { Total } \\
\text { Carbon } \\
(\%)\end{array}$ & $\begin{array}{c}\text { Organic } \\
\text { Carbon } \\
(\%)\end{array}$ & $\begin{array}{c}\mathrm{CaCO}_{3} \\
(\%)\end{array}$ \\
\hline $480-1-1,0$ & 0.00 & 3.5 & 3.3 & 2 \\
\hline $1-1,10$ & 0.10 & 3.6 & 3.3 & 3 \\
\hline $1-1,20$ & 0.20 & 3.5 & 3.4 & 1 \\
\hline $1-1,30$ & 0.30 & 3.6 & 3.3 & 3 \\
\hline $1-1,40$ & 0.40 & 3.4 & 3.2 & 2 \\
\hline $1-1,50$ & 0.50 & 3.8 & 3.4 & 3 \\
\hline $1-1,60$ & 0.60 & 3.5 & 3.2 & 3 \\
\hline $1-1,70$ & 0.70 & 3.3 & 3.0 & 2 \\
\hline $1-1,80$ & 0.80 & 3.5 & 3.3 & 1 \\
\hline $1-1,90$ & 0.90 & 3.6 & 3.3 & 3 \\
\hline $1-1,100$ & 1.00 & 3.5 & 3.0 & 4 \\
\hline $1-1,110$ & 1.10 & 3.5 & 3.2 & 3 \\
\hline $1-1,120$ & 1.20 & 3.6 & 3.4 & 2 \\
\hline $1-1,130$ & 1.30 & 3.9 & 3.3 & 5 \\
\hline $1-1,140$ & 1.40 & 3.6 & 3.2 & 3 \\
\hline $1-2,0$ & 1.50 & 3.7 & 3.3 & 3 \\
\hline $1-2,10$ & 1.60 & 3.4 & 3.1 & 2 \\
\hline $1-2,20$ & 1.70 & 3.4 & 3.1 & 3 \\
\hline $1-2,30$ & 1.80 & 3.9 & 3.4 & 4 \\
\hline $1-2,40$ & 1.90 & 3.7 & 3.4 & 3 \\
\hline $1-2,50$ & 2.00 & 3.5 & 3.1 & 3 \\
\hline $1-2,60$ & 2.10 & 3.5 & 3.1 & 4 \\
\hline $1-2,70$ & 2.20 & 3.5 & 3.1 & 3 \\
\hline $1-2,80$ & 2.30 & 3.6 & 3.2 & 3 \\
\hline $1-2,90$ & 2.40 & 3.5 & 3.0 & 4 \\
\hline $1-2,100$ & 2.50 & 3.7 & 3.0 & 5 \\
\hline $1-2,110$ & 2.60 & 3.7 & 3.2 & 4 \\
\hline $1-2,120$ & 2.70 & 3.5 & 3.1 & 3 \\
\hline $1-2,130$ & 2.80 & 3.5 & 3.2 & 2 \\
\hline $1-2,140$ & 2.90 & 3.7 & 3.2 & 4 \\
\hline $1-3,0$ & 3.00 & 3.6 & 3.2 & 4 \\
\hline $1-3,10$ & 3.10 & 3.9 & 3.5 & 4 \\
\hline $1-3,20$ & 3.20 & 3.7 & 3.4 & 3 \\
\hline $1-3,30$ & 3.30 & 3.5 & 3.2 & 3 \\
\hline $1-3,40$ & 3.40 & 3.4 & 3.1 & 3 \\
\hline $1-3,50$ & 3.50 & 3.5 & 3.1 & 3 \\
\hline $1-3,60$ & 3.60 & 3.5 & 3.1 & 4 \\
\hline $1-3,70$ & 3.70 & 3.8 & 3.3 & 4 \\
\hline $2-1,10$ & 4.85 & 3.5 & 3.1 & 3 \\
\hline $2-1,30$ & 5.05 & 3.7 & 3.2 & 4 \\
\hline $2-1,40$ & 5.15 & 3.7 & 3.4 & 3 \\
\hline $2-1,50$ & 5.25 & 3.6 & 3.1 & 4 \\
\hline $2-1,60$ & 5.35 & 3.3 & 2.9 & 3 \\
\hline $2-1,70$ & 5.45 & 2.8 & 2.7 & 1 \\
\hline $2-1,80$ & 5.55 & 2.9 & 2.7 & 2 \\
\hline $2-2,0$ & 6.25 & 3.8 & 3.4 & 4 \\
\hline $2-2,10$ & 6.35 & 3.5 & 3.1 & 4 \\
\hline $2-2,20$ & 6.45 & 3.7 & 3.2 & 4 \\
\hline $2-2,30$ & 6.55 & 4.1 & 3.6 & 5 \\
\hline $2-2,40$ & 6.65 & 3.4 & 2.9 & 4 \\
\hline $2-2,50$ & 6.75 & 3.6 & 3.2 & 4 \\
\hline $2-2,60$ & 6.85 & 3.4 & 3.1 & 3 \\
\hline $2-2,70$ & 6.95 & 3.6 & 3.3 & 3 \\
\hline $2-2,80$ & 7.05 & 3.6 & 3.1 & 3 \\
\hline $2-2,90$ & 7.15 & 3.3 & 3.0 & 3 \\
\hline $2-2,100$ & 7.25 & 3.6 & 3.1 & 4 \\
\hline $2-2,110$ & 7.35 & 3.8 & 3.4 & 3 \\
\hline $2-2,120$ & 7.45 & 3.4 & 3.1 & 3 \\
\hline $2-2,130$ & 7.55 & 3.5 & 3.0 & 4 \\
\hline $2-2,140$ & 7.65 & 3.3 & 2.9 & 3 \\
\hline $2-3,0$ & 7.75 & 3.4 & 3.1 & 3 \\
\hline $2-3,10$ & 7.85 & 3.6 & 3.1 & 4 \\
\hline $2-3,20$ & 7.95 & 3.4 & 2.9 & 4 \\
\hline $2-3,30$ & 8.05 & 3.4 & 2.8 & 5 \\
\hline $2-3,40$ & 8.15 & 3.5 & 3.0 & 4 \\
\hline $2-3,50$ & 8.25 & 3.3 & 2.9 & 3 \\
\hline
\end{tabular}


Appendix. (Continued).

\begin{tabular}{|c|c|c|c|c|}
\hline $\begin{array}{c}\text { Sample } \\
\text { (level in cm) }\end{array}$ & $\begin{array}{l}\text { Sub-bottom } \\
\text { Depth } \\
\text { (m) }\end{array}$ & $\begin{array}{c}\text { Total } \\
\text { Carbon } \\
(\%)\end{array}$ & $\begin{array}{c}\text { Organic } \\
\text { Carbon } \\
(\%)\end{array}$ & $\begin{array}{c}\mathrm{CaCO}_{3} \\
(\%)\end{array}$ \\
\hline $2-3,60$ & 8.35 & 3.3 & 3.0 & 2 \\
\hline $2-3,70$ & 8.45 & 3.4 & 3.1 & 3 \\
\hline $2-3,80$ & 8.55 & 3.5 & 3.1 & 4 \\
\hline $2-3,90$ & 8.65 & 3.6 & 3.3 & 2 \\
\hline $3-1,0$ & 9.50 & 4.0 & 3.0 & 8 \\
\hline $3-1,20$ & 9.70 & 3.6 & 2.9 & 6 \\
\hline $3-1,30$ & 9.80 & 3.6 & 2.8 & 7 \\
\hline $3-1,40$ & 9.90 & 3.6 & 2.8 & 7 \\
\hline $3-1,50$ & 10.00 & 3.6 & 2.7 & 8 \\
\hline $3-1,60$ & 10.10 & 3.2 & 2.8 & 3 \\
\hline $3-1,70$ & 10.20 & 3.2 & 2.8 & 3 \\
\hline $3-1,80$ & 10.30 & 3.4 & 2.7 & 6 \\
\hline $3-1,90$ & 10.40 & 3.3 & 3.0 & 3 \\
\hline $3-1,100$ & 10.50 & 4.7 & 2.7 & 16 \\
\hline $3-1,110$ & 10.60 & 4.9 & 2.9 & 17 \\
\hline $3-1,120$ & 10.70 & 4.8 & 2.8 & 17 \\
\hline $3-1,130$ & 10.80 & 4.9 & 2.7 & 18 \\
\hline $3-2,0$ & 11.00 & 5.0 & 2.8 & 19 \\
\hline $3-2,10$ & 11.10 & 4.7 & 2.6 & 18 \\
\hline $3-2,20$ & 11.20 & 4.1 & 2.7 & 12 \\
\hline $3-2,30$ & 11.30 & 3.5 & 2.7 & 7 \\
\hline $3-2,40$ & 11.40 & 3.2 & 2.8 & 3 \\
\hline $3-2,50$ & 11.50 & 3.0 & 2.4 & 5 \\
\hline $3-2,60$ & 11.60 & 2.9 & 2.4 & 4 \\
\hline $3-2,70$ & 11.70 & 3.2 & 2.7 & 4 \\
\hline $3-2,80$ & 11.80 & 2.7 & 2.4 & 2 \\
\hline $3-2,90$ & 11.90 & 3.0 & 2.6 & 3 \\
\hline $3-2,100$ & 12.00 & 2.7 & 2.4 & 2 \\
\hline $3-2,110$ & 12.10 & 2.8 & 2.4 & 3 \\
\hline $3-2,120$ & 12.20 & 2.6 & 2.4 & 2 \\
\hline $3-2,130$ & 12.30 & 2.9 & 2.6 & 2 \\
\hline $3-2,140$ & 12.40 & 2.6 & 2.3 & 2 \\
\hline $3-3,0$ & 12.50 & 2.5 & 2.2 & 3 \\
\hline $3-3,10$ & 12.60 & 2.6 & 2.2 & 4 \\
\hline $3-3,20$ & 12.70 & 2.7 & 2.3 & 3 \\
\hline $3-3,30$ & 12.80 & 2.9 & 2.4 & 5 \\
\hline $3-3,40$ & 12.90 & 3.2 & 2.2 & 8 \\
\hline $3-3,50$ & 13.00 & 4.4 & 2.5 & 15 \\
\hline $3-3,60$ & 13.10 & 4.8 & 2.6 & 18 \\
\hline $3-3,91$ & 13.41 & 5.4 & 2.9 & 21 \\
\hline $3-3,100$ & 13.50 & 4.7 & 2.9 & 15 \\
\hline $3-3,110$ & 13.60 & 3.9 & 2.6 & 11 \\
\hline $3-3,120$ & 13.70 & 3.9 & 2.6 & 10 \\
\hline $4-1,20$ & 14.45 & 3.8 & 2.5 & 11 \\
\hline $4-1,40$ & 14.65 & 3.9 & 2.5 & 11 \\
\hline $4-1,60$ & 14.85 & 3.8 & 2.7 & 10 \\
\hline $4-1,75$ & 15.00 & 3.9 & 2.3 & 13 \\
\hline $4-1,90$ & 15.15 & 3.9 & 2.4 & 12 \\
\hline $4-1,110$ & 15.35 & 4.0 & 2.5 & 13 \\
\hline $4-1,130$ & 15.55 & 4.2 & 2.7 & 12 \\
\hline $4-2,0$ & 15.75 & 4.0 & 2.5 & 12 \\
\hline $4-2,10$ & 15.85 & 4.0 & 2.5 & 13 \\
\hline $4-2,30$ & 16.05 & 4.2 & 2.5 & 14 \\
\hline $4-2,40$ & 16.15 & 4.0 & 2.5 & 12 \\
\hline $4-2,40$ & 16.15 & 3.8 & 2.6 & 10 \\
\hline $4-2,50$ & 16.25 & 3.9 & 2.7 & 10 \\
\hline $4-2,60$ & 16.35 & 3.7 & 2.7 & 8 \\
\hline $4-2,70$ & 16.45 & 3.4 & 2.9 & 4 \\
\hline $4-2,80$ & 16.55 & 3.5 & 2.7 & 7 \\
\hline $4-2,90$ & 16.65 & 4.2 & 2.7 & 12 \\
\hline $4-2,100$ & 16.75 & 4.2 & 2.8 & 12 \\
\hline $4-2,110$ & 16.85 & 4.1 & 2.6 & 12 \\
\hline $4-2,120$ & 16.95 & 4.2 & 2.9 & 11 \\
\hline $4-2,130$ & 17.05 & 4.1 & 2.7 & 11 \\
\hline $4-2,140$ & 17.15 & 3.8 & 2.9 & 7 \\
\hline $4-3,0$ & 17.25 & 3.8 & 3.0 & 6 \\
\hline $4-3,10$ & 17.35 & 3.9 & 3.0 & 7 \\
\hline $4-3,20$ & 17.45 & 3.7 & 2.9 & 7 \\
\hline
\end{tabular}

Appendix. (Continued).

\begin{tabular}{|c|c|c|c|c|}
\hline $\begin{array}{c}\text { Sample } \\
\text { (level in } \mathrm{cm} \text { ) }\end{array}$ & $\begin{array}{l}\text { Sub-bottom } \\
\text { Depth }^{\mathrm{a}} \\
(\mathrm{m})\end{array}$ & $\begin{array}{c}\text { Total } \\
\text { Carbon } \\
(\%)\end{array}$ & $\begin{array}{c}\text { Organic } \\
\text { Carbon } \\
(\%)\end{array}$ & $\begin{array}{c}\mathrm{CaCO}_{3} \\
(\%)\end{array}$ \\
\hline $4-3,30$ & 17.55 & 3.7 & 2.8 & 8 \\
\hline $4-3,40$ & 17.65 & 3.8 & 2.8 & 8 \\
\hline $4-3,50$ & 17.75 & 4.0 & 2.9 & 9 \\
\hline $4-3,60$ & 17.85 & 4.3 & 3.0 & 11 \\
\hline $4-3,80$ & 18.05 & 4.0 & 2.9 & 10 \\
\hline $4-3,90$ & 18.15 & 3.7 & 2.8 & 7 \\
\hline $4-3,100$ & 18.25 & 3.6 & 2.8 & 7 \\
\hline $4-3,110$ & 18.35 & 3.6 & 2.6 & 8 \\
\hline $5-1,15$ & 19.15 & 3.9 & 2.8 & 9 \\
\hline $5-1,30$ & 19.30 & 3.9 & 2.7 & 10 \\
\hline $5-1,40$ & 19.40 & 4.1 & 3.0 & 9 \\
\hline $5-1,50$ & 19.50 & 3.7 & 3.1 & 5 \\
\hline $5-1,60$ & 19.60 & 3.8 & 3.3 & 5 \\
\hline $5-1,70$ & 19.70 & 3.4 & 3.1 & 3 \\
\hline $5-1,80$ & 19.80 & 4.0 & 3.0 & 8 \\
\hline $5-1,90$ & 19.90 & 4.1 & 3.1 & 8 \\
\hline $5-1,100$ & 20.00 & 3.9 & 3.2 & 6 \\
\hline $5-1,110$ & 20.10 & 3.2 & 3.1 & 1 \\
\hline $5-1,120$ & 20.20 & 3.4 & 3.1 & 3 \\
\hline $5-1,135$ & 20.35 & 3.3 & 3.1 & 1 \\
\hline $5-2,0$ & 20.50 & 3.4 & 3.0 & 4 \\
\hline $5-2,20$ & 20.70 & 3.4 & 3.1 & 3 \\
\hline $5-2,30$ & 20.80 & 3.4 & 3.0 & 3 \\
\hline $5-2,50$ & 21.00 & 3.2 & 3.0 & 2 \\
\hline $5-2,70$ & 21.20 & 3.6 & 3.2 & 3 \\
\hline $5-2,80$ & 21.30 & 3.4 & 3.2 & 2 \\
\hline $5-2,90$ & 21.40 & 3.3 & 2.9 & 3 \\
\hline $5-2,100$ & 21.50 & 3.3 & 2.9 & 3 \\
\hline $5-2,110$ & 21.60 & 3.5 & 3.3 & 2 \\
\hline $5-2,120$ & 21.70 & 3.5 & 2.9 & 5 \\
\hline $5-2,135$ & 21.85 & 3.1 & 2.9 & 2 \\
\hline $5-3,0$ & 22.00 & 4.1 & 3.2 & 8 \\
\hline $5-3,10$ & 22.10 & 3.6 & 3.2 & 3 \\
\hline $5-3,30$ & 22.30 & 3.5 & 3.0 & 5 \\
\hline $5-3,40$ & 22.40 & 3.9 & 3.2 & 6 \\
\hline $5-3,50$ & 22.50 & 3.4 & 3.1 & 3 \\
\hline $5-3,60$ & 22.60 & 3.7 & 2.8 & 7 \\
\hline $5-3,70$ & 22.70 & 3.3 & 3.1 & 2 \\
\hline $6-1,0$ & 23.75 & 3.6 & 3.0 & 5 \\
\hline $6-1,20$ & 23.95 & 3.4 & 2.7 & 6 \\
\hline $6-1,30$ & 24.05 & 2.7 & 2.3 & 3 \\
\hline $6-1,40$ & 24.15 & 3.5 & 2.7 & 7 \\
\hline $6-1,60$ & 24.35 & 3.1 & 2.7 & 4 \\
\hline $6-1,80$ & 24.55 & 3.0 & 2.6 & 3 \\
\hline $6-1,100$ & 24.75 & 2.9 & 2.5 & 3 \\
\hline $6-1,120$ & 24.95 & 2.8 & 2.5 & 2 \\
\hline $6-2,0$ & 25.25 & 2.8 & 2.6 & 1 \\
\hline $6-2,10$ & 25.35 & 2.8 & 2.6 & 2 \\
\hline $6-2,20$ & 25.45 & 3.0 & 2.8 & 2 \\
\hline $6-2,30$ & 25.55 & 3.2 & 2.5 & 6 \\
\hline $6-2,70$ & 25.95 & 3.0 & 2.8 & 1 \\
\hline $6-2,80$ & 26.05 & 2.7 & 2.7 & 1 \\
\hline $6-2,90$ & 26.15 & 2.8 & 2.7 & 1 \\
\hline $6-2,100$ & 26.25 & 2.7 & 2.3 & 3 \\
\hline $6-2,110$ & 26.35 & 2.6 & 2.5 & 1 \\
\hline $6-2,120$ & 26.45 & 2.6 & 2.5 & 1 \\
\hline $6-2,130$ & 26.55 & 2.9 & 2.5 & 4 \\
\hline $6-3,0$ & 26.75 & 3.0 & 2.8 & 2 \\
\hline $6-3,20$ & 26.95 & 3.0 & 2.8 & 1 \\
\hline $6-3,30$ & 27.05 & 3.0 & 2.7 & 3 \\
\hline $6-3,50$ & 27.25 & 3.0 & 2.6 & 3 \\
\hline $6-3,60$ & 27.35 & 2.9 & 2.6 & 3 \\
\hline $6-3,70$ & 27.45 & 2.9 & 2.5 & 3 \\
\hline $6-3,85$ & 27.60 & 2.6 & 2.4 & 2 \\
\hline $6-3,100$ & 27.75 & 2.5 & 2.3 & 2 \\
\hline $6-3,110$ & 27.85 & 2.5 & 2.2 & 3 \\
\hline $6-3,120$ & 27.95 & 2.5 & 2.2 & 3 \\
\hline $7-1,0$ & 28.50 & 3.0 & 2.7 & 2 \\
\hline
\end{tabular}


Appendix. (Continued).

\begin{tabular}{|c|c|c|c|c|}
\hline $\begin{array}{c}\text { Sample } \\
\text { (level in } \mathrm{cm} \text { ) }\end{array}$ & $\begin{array}{l}\text { Sub-bottom } \\
\text { Depth }^{\mathrm{a}} \\
\text { (m) }\end{array}$ & $\begin{array}{c}\text { Total } \\
\text { Carbon } \\
(\%)\end{array}$ & $\begin{array}{c}\text { Organic } \\
\text { Carbon } \\
(\%)\end{array}$ & $\begin{array}{c}\mathrm{CaCO}_{3} \\
(\%)\end{array}$ \\
\hline $7-1,20$ & 28.70 & 3.0 & 2.6 & 4 \\
\hline $7-1,30$ & 28.80 & 3.0 & 2.6 & 4 \\
\hline $7-1,40$ & 28.90 & 2.7 & 2.6 & 1 \\
\hline $7-1,50$ & 29.00 & 2.7 & 2.4 & 3 \\
\hline $7-1,60$ & 29.10 & 2.8 & 2.6 & 2 \\
\hline $7-1,70$ & 29.20 & 3.0 & 2.6 & 3 \\
\hline $7-1,80$ & 29.30 & 2.7 & 2.2 & 4 \\
\hline $7-1,90$ & 29.40 & 3.3 & 2.8 & 4 \\
\hline $7-1,110$ & 29.60 & 3.3 & 2.6 & 5 \\
\hline $7-1,120$ & 29.70 & 3.1 & 2.8 & 3 \\
\hline $7-1,130$ & 29.80 & 2.9 & 2.5 & 4 \\
\hline $7-2,0$ & 30.00 & 3.6 & 3.0 & 5 \\
\hline $7-2,10$ & 30.10 & 3.7 & 2.7 & 8 \\
\hline $7-2,20$ & 30.20 & 3.9 & 3.0 & 8 \\
\hline $7-2,30$ & 30.30 & 4.5 & 3.1 & 11 \\
\hline $7-2,40$ & 30.40 & 3.5 & 2.9 & 5 \\
\hline $7-2,50$ & 30.50 & 3.4 & 3.0 & 3 \\
\hline $7-2,60$ & 30.60 & 3.5 & 3.4 & 1 \\
\hline $7-2,70$ & 30.70 & 3.3 & 2.8 & 4 \\
\hline $7-2,80$ & 30.80 & 3.4 & 3.4 & 0 \\
\hline $7-2,90$ & 30.90 & 3.5 & 2.7 & 6 \\
\hline $7-2,100$ & 31.00 & 3.7 & 3.2 & 5 \\
\hline $7-2,110$ & 31.10 & 3.7 & 2.9 & 7 \\
\hline $7-2,120$ & 31.20 & 3.9 & 3.6 & 3 \\
\hline $7-2,130$ & 31.30 & 4.7 & 3.4 & 11 \\
\hline $7-2,140$ & 31.40 & 4.0 & 3.1 & 7 \\
\hline $7-3,0$ & 31.50 & 3.5 & 2.9 & 5 \\
\hline $7-3,10$ & 31.60 & 2.7 & 2.7 & 0 \\
\hline $7-3,20$ & 31.70 & 2.9 & 2.7 & 2 \\
\hline $7-3,30$ & 31.80 & 2.8 & 2.6 & 1 \\
\hline $7-3,40$ & 31.90 & 3.2 & 2.9 & 2 \\
\hline $7-3,50$ & 32.00 & 2.8 & 2.5 & 2 \\
\hline $7-3,60$ & 32.10 & 2.8 & 2.5 & 2 \\
\hline $7-3,70$ & 32.20 & 2.7 & 2.4 & 2 \\
\hline $7-3,80$ & 32.30 & 2.9 & 2.7 & 2 \\
\hline $7-3,90$ & 32.40 & 4.1 & 3.4 & 6 \\
\hline $7-3,110$ & 32.60 & 4.0 & 2.5 & 12 \\
\hline $8-1,0$ & 33.25 & 3.1 & 2.6 & 4 \\
\hline $8-1,40$ & 33.65 & 3.2 & 3.0 & 2 \\
\hline $8-1,80$ & 34.05 & 3.2 & 2.6 & 5 \\
\hline $8-1,120$ & 34.45 & 3.4 & 2.9 & 4 \\
\hline $8-2,0$ & 34.75 & 2.9 & 2.8 & 1 \\
\hline $8-2,40$ & 35.15 & 3.2 & 2.3 & 8 \\
\hline $8-2,80$ & 35.55 & 3.1 & 2.2 & 7 \\
\hline $8-2,100$ & 35.75 & 2.9 & 2.4 & 4 \\
\hline $8-2,120$ & 35.95 & 3.3 & 2.6 & 7 \\
\hline $8-3,0$ & 36.25 & 3.4 & 2.4 & 9 \\
\hline $8-3,40$ & 36.65 & 3.8 & 2.5 & 11 \\
\hline $8-3,80$ & 37.05 & 3.8 & 2.8 & 8 \\
\hline $8-3,120$ & 37.45 & 3.7 & 2.6 & 10 \\
\hline $9-1,60$ & 38.60 & 3.4 & 2.9 & 5 \\
\hline $9-1,100$ & 39.00 & 3.7 & 3.3 & 4 \\
\hline $9-1,140$ & 39.40 & 3.5 & 2.7 & 7 \\
\hline $9-2,20$ & 39.70 & 3.1 & 2.7 & 3 \\
\hline $9-2,60$ & 40.10 & 3.3 & 2.4 & 8 \\
\hline $9-2,100$ & 40.50 & 3.4 & 2.6 & 7 \\
\hline $9-3,0$ & 41.00 & 3.2 & 2.3 & 8 \\
\hline $9-3,40$ & 41.40 & 2.9 & 2.4 & 5 \\
\hline $10-1,0$ & 42.75 & 3.7 & 2.6 & 9 \\
\hline $10-1,50$ & 43.25 & 3.1 & 2.7 & 3 \\
\hline $10-1,80$ & 43.55 & 3.5 & 2.2 & 11 \\
\hline $10-1,100$ & 43.75 & 2.9 & 2.1 & 7 \\
\hline $10-1,120$ & 43.95 & 3.1 & 2.0 & 9 \\
\hline $10-2,0$ & 44.25 & 2.9 & 2.5 & 3 \\
\hline $10-2,20$ & 44.45 & 3.2 & 2.1 & 9 \\
\hline $10-2,40$ & 44.65 & 2.9 & 2.3 & 5 \\
\hline $10-2,60$ & 44.85 & 3.0 & 2.2 & 7 \\
\hline $10-2,80$ & 45.05 & 2.6 & 2.3 & 2 \\
\hline
\end{tabular}

Appendix. (Continued).

\begin{tabular}{|c|c|c|c|c|}
\hline $\begin{array}{c}\text { Sample }{ }^{\mathrm{a}} \\
\text { (level in cm) }\end{array}$ & $\begin{array}{l}\text { Sub-bottom } \\
\text { Deptha } \\
\text { (m) }\end{array}$ & $\begin{array}{c}\text { Total } \\
\text { Carbon } \\
(\%)\end{array}$ & $\begin{array}{c}\text { Organic } \\
\text { Carbon } \\
(\%)\end{array}$ & $\begin{array}{c}\mathrm{CaCO}_{3} \\
(\%)\end{array}$ \\
\hline $10-2,100$ & 45.25 & 2.4 & 1.9 & 4 \\
\hline $10-2,120$ & 45.45 & 2.6 & 1.9 & 6 \\
\hline $10-3,0$ & 45.75 & 2.7 & 2.3 & 3 \\
\hline $10-3,20$ & 45.95 & 2.7 & 2.4 & 2 \\
\hline $10-3,40$ & 46.15 & 3.0 & 2.3 & 5 \\
\hline $10-3,60$ & 46.35 & 3.4 & 2.3 & 9 \\
\hline $10-3,80$ & 46.55 & 3.5 & 2.2 & 11 \\
\hline $10-3,100$ & 46.75 & 3.2 & 2.2 & 8 \\
\hline $10-3,120$ & 46.95 & 3.6 & 2.4 & 10 \\
\hline $11-1,20$ & 47.70 & 3.1 & 2.3 & 7 \\
\hline $11-1,60$ & 48.10 & 4.0 & 2.4 & 13 \\
\hline $11-1,90$ & 48.40 & 3.0 & 2.4 & 6 \\
\hline $11-1,116$ & 48.66 & 4.1 & 2.2 & 16 \\
\hline $13-1,24$ & 61.99 & 2.2 & 1.3 & 8 \\
\hline $13-1,80$ & 62.55 & 3.9 & 2.2 & 14 \\
\hline $13-1,120$ & 62.95 & 3.4 & 2.2 & 10 \\
\hline $13-2,10$ & 63.35 & 4.4 & 2.6 & 16 \\
\hline $13-2,30$ & 63.55 & 3.6 & 2.4 & 10 \\
\hline $13-2,50$ & 63.75 & 3.3 & 2.9 & 4 \\
\hline $13-2,70$ & 63.95 & 2.9 & 2.4 & 4 \\
\hline $13-2,90$ & 64.15 & 3.0 & 2.5 & 5 \\
\hline $13-2,110$ & 64.35 & 3.4 & 2.5 & 8 \\
\hline $13-2,130$ & 64.55 & 2.9 & 2.2 & 5 \\
\hline $13-3,0$ & 64.75 & 3.9 & 2.4 & 13 \\
\hline $13-3,30$ & 65.05 & 3.2 & 2.7 & 5 \\
\hline $13-3,60$ & 65.35 & 3.5 & 2.5 & 9 \\
\hline $14-1,0$ & 66.50 & 3.4 & 2.4 & 8 \\
\hline $14-1,30$ & 66.80 & 4.0 & 2.6 & 11 \\
\hline $14-1,50$ & 67.00 & 4.4 & 2.7 & 14 \\
\hline $14-1,70$ & 67.20 & 3.6 & 2.8 & 6 \\
\hline $14-1,90$ & 67.40 & 4.0 & 2.4 & 13 \\
\hline $14-1,120$ & 67.70 & 3.7 & 2.5 & 10 \\
\hline $14-2,40$ & 68.40 & 4.3 & 2.5 & 15 \\
\hline $14-2,80$ & 68.80 & 3.6 & 2.6 & 9 \\
\hline $14-2,120$ & 69.20 & 3.9 & 2.5 & 11 \\
\hline $14-3,9$ & 69.59 & 3.5 & 2.3 & 10 \\
\hline $14-3,30$ & 69.80 & 3.4 & 2.1 & 11 \\
\hline $14-3,50$ & 70.00 & 3.7 & 2.0 & 14 \\
\hline $14-3,90$ & 70.40 & 3.4 & 2.5 & 7 \\
\hline $15-1,20$ & 71.45 & 3.3 & 2.4 & 7 \\
\hline $15-1,40$ & 71.65 & 2.9 & 2.8 & 0 \\
\hline $15-1,80$ & 72.05 & 3.3 & 2.8 & 4 \\
\hline $15-1,120$ & 72.45 & 2.9 & 2.4 & 4 \\
\hline $15-2,40$ & 73.15 & 3.2 & 2.1 & 9 \\
\hline $15-2,110$ & 73.85 & 2.9 & 2.6 & 3 \\
\hline $15-3,55$ & 74.80 & 3.0 & 2.3 & 6 \\
\hline $16-1,18$ & 76.18 & 2.9 & 2.9 & 0 \\
\hline $16-1,60$ & 76.60 & 2.8 & 2.8 & 0 \\
\hline $16-1,97$ & 76.97 & 3.0 & 3.0 & 0 \\
\hline $16-1,123$ & 77.23 & 2.8 & 2.3 & 4 \\
\hline $16-2,0$ & 77.50 & 3.5 & 2.5 & 9 \\
\hline $16-2,20$ & 77.70 & 3.7 & 2.5 & 9 \\
\hline $16-2,40$ & 77.90 & 3.7 & 2.5 & 9 \\
\hline $16-2,60$ & 78.10 & 3.3 & 2.7 & 6 \\
\hline $16-2,80$ & 78.30 & 3.3 & 2.6 & 6 \\
\hline $16-2,100$ & 78.50 & 3.5 & 2.4 & 9 \\
\hline $16-2,120$ & 78.70 & 3.5 & 2.6 & 8 \\
\hline $16-2,140$ & 78.90 & 3.7 & 2.6 & 9 \\
\hline $16-3,10$ & 79.10 & 3.7 & 2.3 & 12 \\
\hline $16-3,30$ & 79.30 & 3.8 & 2.2 & 14 \\
\hline $16-3,50$ & 79.50 & 3.8 & 2.1 & 14 \\
\hline $16-3,70$ & 79.70 & 3.8 & 2.1 & 14 \\
\hline $16-3,90$ & 79.90 & 2.6 & 2.2 & 3 \\
\hline $16-3,110$ & 80.10 & 2.5 & 2.4 & 1 \\
\hline $17-1,0$ & 80.75 & 2.8 & 2.4 & 3 \\
\hline $17-1,87$ & 81.62 & 2.9 & 2.6 & 2 \\
\hline $17-2,0$ & 82.25 & 2.5 & 2.3 & 2 \\
\hline $17-2,70$ & 82.95 & 2.5 & 2.4 & 1 \\
\hline
\end{tabular}


Appendix. (Continued).

\begin{tabular}{|c|c|c|c|c|}
\hline $\begin{array}{c}\text { Sample }{ }^{\mathrm{a}} \\
(\text { level in } \mathrm{cm})\end{array}$ & $\begin{array}{l}\text { Sub-bottom } \\
\text { Depth } \\
\text { (m) }\end{array}$ & $\begin{array}{c}\text { Total } \\
\text { Carbon } \\
(\%)\end{array}$ & $\begin{array}{c}\text { Organic } \\
\text { Carbon } \\
(\%)\end{array}$ & $\begin{array}{c}\mathrm{CaCO}_{3} \\
(\%)\end{array}$ \\
\hline $17-2,125$ & 83.50 & 2.1 & 2.1 & 1 \\
\hline $17-3,25$ & 84.00 & 2.2 & 2.1 & 1 \\
\hline $17-3,70$ & 84.45 & 2.2 & 2.1 & 0 \\
\hline $17-3,110$ & 84.85 & 2.5 & 2.4 & 1 \\
\hline $18-1,30$ & 85.80 & 2.9 & 2.7 & 1 \\
\hline $18-1,50$ & 86.00 & 3.1 & 2.8 & 2 \\
\hline $18-1,70$ & 86.20 & 2.8 & 2.6 & 1 \\
\hline $18-1,90$ & 86.40 & 2.5 & 2.4 & 1 \\
\hline $18-1,110$ & 86.60 & 2.7 & 2.6 & 1 \\
\hline $18-1,130$ & 86.80 & 2.8 & 2.6 & 1 \\
\hline $18-2,0$ & 87.00 & 3.0 & 2.8 & 2 \\
\hline $18-2,20$ & 87.20 & 3.0 & 2.8 & 2 \\
\hline $18-2,40$ & 87.40 & 3.1 & 2.8 & 2 \\
\hline $18-2,60$ & 87.60 & 2.8 & 2.6 & 1 \\
\hline $18-2,80$ & 87.80 & 3.1 & 2.9 & 1 \\
\hline $18-2,100$ & 88.00 & 2.9 & 2.7 & 2 \\
\hline $18-2,120$ & 88.20 & 3.3 & 3.1 & 2 \\
\hline $18-2,140$ & 88.40 & 3.5 & 3.0 & 4 \\
\hline $18-3,80$ & 89.30 & 3.5 & 3.3 & 2 \\
\hline $18-3,113$ & 89.63 & 3.5 & 3.1 & 4 \\
\hline $19-1,40$ & 90.65 & 3.0 & 2.8 & 1 \\
\hline $19-1,70$ & 90.95 & 3.0 & 3.0 & 0 \\
\hline $19-1,90$ & 91.15 & 2.8 & 2.7 & 1 \\
\hline $19-1,110$ & 91.35 & 2.9 & 2.5 & 3 \\
\hline $19-2,0$ & 91.75 & 4.7 & 2.6 & 17 \\
\hline $19-2,40$ & 92.15 & 3.4 & 2.5 & 8 \\
\hline $19-2,80$ & 92.55 & 3.2 & 2.3 & 7 \\
\hline $19-2,120$ & 92.95 & 2.6 & 2.6 & 0 \\
\hline $19-3,14$ & 93.39 & 2.5 & 2.4 & 1 \\
\hline $19-3,40$ & 93.65 & 3.5 & 2.7 & 7 \\
\hline $19-3,90$ & 94.15 & 2.6 & 2.2 & 3 \\
\hline $20-1,30$ & 95.30 & 3.4 & 3.3 & 0 \\
\hline $20-1,50$ & 95.50 & 3.1 & 3.0 & 0 \\
\hline $20-1,70$ & 95.70 & 3.0 & 3.0 & 0 \\
\hline $20-1,110$ & 96.10 & 2.9 & 2.9 & 0 \\
\hline $20-1,130$ & 96.30 & 2.9 & 2.8 & 0 \\
\hline $20-2,0$ & 96.50 & 3.0 & 3.0 & 0 \\
\hline $20-2,20$ & 96.70 & 2.8 & 2.7 & 0 \\
\hline $20-2,40$ & 96.90 & 1.9 & 1.9 & 0 \\
\hline $20-2,60$ & 97.10 & 2.8 & 2.8 & 0 \\
\hline $20-2,80$ & 97.30 & 2.7 & 2.7 & 0 \\
\hline $20-2,100$ & 97.50 & 3.0 & 2.8 & 1 \\
\hline $20-2,120$ & 97.70 & 2.9 & 2.9 & 0 \\
\hline $20-3,0$ & 98.00 & 3.0 & 2.9 & 0 \\
\hline $20-3,20$ & 98.20 & 2.9 & 2.8 & 1 \\
\hline $20-3,40$ & 98.40 & 2.9 & 2.8 & 1 \\
\hline $21-1,0$ & 99.75 & 2.9 & 2.9 & 0 \\
\hline $21-1,60$ & 100.35 & 3.2 & 3.1 & 1 \\
\hline $21-1,80$ & 100.55 & 3.1 & 3.0 & 1 \\
\hline $21-1,100$ & 100.75 & 6.5 & 1.9 & 38 \\
\hline $21-1,100$ & 100.75 & 6.3 & 1.8 & 37 \\
\hline $21-2,0$ & 101.25 & 1.5 & 1.6 & 0 \\
\hline $21-2,20$ & 101.45 & 1.4 & 1.6 & -2 \\
\hline $21-2,20$ & 101.45 & 1.5 & 1.4 & 1 \\
\hline $21-2,40$ & 101.65 & 1.9 & 1.5 & 3 \\
\hline $21-2,60$ & 101.85 & 2.3 & 2.1 & 2 \\
\hline $21-2,60$ & 101.85 & 2.4 & 1.8 & 5 \\
\hline $21-2,80$ & 102.05 & 3.1 & 2.3 & 7 \\
\hline $21-2,110$ & 102.35 & 3.0 & 2.4 & 4 \\
\hline $21-2,110$ & 102.35 & 3.2 & 2.2 & 9 \\
\hline $21-2,130$ & 102.55 & 4.2 & 3.1 & 9 \\
\hline $21-3,0$ & 102.75 & 5.7 & 3.6 & 18 \\
\hline $21-3,0$ & 102.75 & 5.8 & 3.3 & 21 \\
\hline $21-3,30$ & 103.05 & 5.0 & 3.3 & 15 \\
\hline $21-3,60$ & 103.35 & 4.7 & 2.9 & 15 \\
\hline $21-3,90$ & 103.65 & 4.6 & 2.7 & 15 \\
\hline $21-3,110$ & 103.85 & 4.5 & 3.1 & 12 \\
\hline $22-1,40$ & 104.90 & 3.6 & 2.6 & 9 \\
\hline
\end{tabular}

Appendix. (Continued).

\begin{tabular}{|c|c|c|c|c|}
\hline $\begin{array}{c}\text { Sample }{ }^{\mathrm{a}} \\
\text { (level in cm) }\end{array}$ & $\begin{array}{l}\text { Sub-bottom } \\
\text { Depth } \\
\text { (m) }\end{array}$ & $\begin{array}{c}\text { Total } \\
\text { Carbon } \\
(\%)\end{array}$ & $\begin{array}{c}\text { Organic } \\
\text { Carbon } \\
(\%)\end{array}$ & $\begin{array}{c}\mathrm{CaCO}_{3} \\
(\%)\end{array}$ \\
\hline $22-1,80$ & 105.30 & 2.9 & 2.9 & 1 \\
\hline $22-1,100$ & 105.50 & 2.8 & 2.7 & 1 \\
\hline $22-1,120$ & 105.70 & 3.4 & 2.7 & 6 \\
\hline $22-1,140$ & 105.90 & 3.6 & 2.6 & 8 \\
\hline $22-2,30$ & 106.30 & 3.7 & 2.5 & 10 \\
\hline $22-2,60$ & 106.60 & 3.8 & 2.5 & 10 \\
\hline $22-2,80$ & 106.80 & 3.7 & 2.8 & 7 \\
\hline $22-2,100$ & 107.00 & 2.8 & 2.8 & 0 \\
\hline $22-2,120$ & 107.20 & 2.8 & 2.7 & 1 \\
\hline $22-2,140$ & 107.40 & 2.6 & 2.6 & 0 \\
\hline $22-3,10$ & 107.60 & 2.4 & 2.3 & 1 \\
\hline $22-3,30$ & 107.80 & 2.6 & 2.6 & 0 \\
\hline $22-3,50$ & 108.00 & 2.5 & 2.5 & 0 \\
\hline $22-3,70$ & 108.20 & 2.6 & 2.5 & 1 \\
\hline $22-3,90$ & 108.40 & 2.7 & 2.6 & 1 \\
\hline $22-3,110$ & 108.60 & 2.8 & 2.8 & 0 \\
\hline $23-1,0$ & 109.25 & 2.7 & 2.6 & 1 \\
\hline $23-1,40$ & 109.65 & 2.5 & 2.5 & 0 \\
\hline $23-1,80$ & 110.05 & 2.5 & 2.5 & 0 \\
\hline $23-1,120$ & 110.45 & 2.6 & 2.5 & 1 \\
\hline $23-2,0$ & 110.75 & 3.0 & 2.9 & 1 \\
\hline $23-2,20$ & 110.95 & 2.5 & 2.5 & 0 \\
\hline $23-2,40$ & 111.15 & 2.4 & 2.4 & 0 \\
\hline $23-3,0$ & 112.25 & 2.6 & 2.5 & 1 \\
\hline $23-3,60$ & 112.85 & 2.6 & 2.6 & 0 \\
\hline $23-3,80$ & 113.05 & 2.5 & 2.5 & 0 \\
\hline $23-3,120$ & 113.45 & 2.6 & 2.6 & 0 \\
\hline $25-1,10$ & 118.85 & 3.2 & 2.9 & 2 \\
\hline $25-1,30$ & 119.05 & 3.0 & 3.0 & 0 \\
\hline $25-1,50$ & 119.25 & 3.1 & 3.1 & 0 \\
\hline $25-1,70$ & 119.45 & 2.9 & 2.9 & 0 \\
\hline $25-1,100$ & 119.75 & 2.7 & 2.6 & 0 \\
\hline $25-1,120$ & 119.95 & 2.8 & 2.8 & 0 \\
\hline $25-1,140$ & 120.15 & 3.3 & 3.2 & 1 \\
\hline $25-2,10$ & 120.35 & 3.1 & 3.1 & 0 \\
\hline $25-2,30$ & 120.55 & 3.3 & 3.3 & 0 \\
\hline $25-2,50$ & 120.75 & 3.3 & 3.3 & 0 \\
\hline $25-2,70$ & 120.95 & 3.5 & 3.6 & 0 \\
\hline $25-2,90$ & 121.15 & 3.5 & 3.5 & 0 \\
\hline $25-2,110$ & 121.35 & 3.1 & 3.1 & 0 \\
\hline $25-2,130$ & 121.55 & 3.1 & 3.1 & 0 \\
\hline $25-3,0$ & 121.75 & 3.0 & 3.0 & 0 \\
\hline $25-3,30$ & 122.05 & 3.2 & 3.1 & 1 \\
\hline $25-3,60$ & 122.35 & 3.0 & 3.0 & 0 \\
\hline $25-3,80$ & 122.55 & 3.3 & 3.2 & 0 \\
\hline $25-3,100$ & 122.75 & 2.9 & 2.9 & 0 \\
\hline $25-3,120$ & 122.95 & 3.0 & 3.0 & 0 \\
\hline $26-1,0$ & 123.50 & 3.1 & 3.1 & 0 \\
\hline $26-1,30$ & 123.80 & 3.2 & 3.2 & 0 \\
\hline $26-1,50$ & 124.00 & 3.2 & 3.2 & 0 \\
\hline $26-1,70$ & 124.20 & 3.3 & 3.2 & 1 \\
\hline $26-1,90$ & 124.40 & 3.3 & 3.3 & 0 \\
\hline $26-1,110$ & 124.60 & 3.1 & 3.0 & 1 \\
\hline $26-1,130$ & 124.80 & 3.3 & 3.3 & 1 \\
\hline $26-2,0$ & 125.00 & 3.3 & 3.2 & 1 \\
\hline $26-2,20$ & 125.20 & 3.2 & 3.1 & 1 \\
\hline $26-2,40$ & 125.40 & 3.4 & 3.3 & 1 \\
\hline $26-2,60$ & 125.60 & 3.5 & 3.4 & 1 \\
\hline $26-2,80$ & 125.80 & 3.0 & 2.9 & 1 \\
\hline $26-2,100$ & 126.00 & 3.2 & 3.1 & 1 \\
\hline $26-2,120$ & 126.20 & 3.2 & 3.1 & 1 \\
\hline $26-2,140$ & 126.40 & 3.5 & 3.2 & 2 \\
\hline $26-3,70$ & 127.20 & 3.5 & 2.9 & 5 \\
\hline $27-1,0$ & 128.25 & 3.5 & 2.7 & 7 \\
\hline $27-1,32$ & 128.57 & 3.0 & 2.9 & 1 \\
\hline $27-1,107$ & 129.32 & 2.9 & 3.0 & 0 \\
\hline $27-1,135$ & 129.60 & 2.8 & 2.7 & 0 \\
\hline $27-2,16$ & 129.91 & 2.6 & 2.6 & 0 \\
\hline
\end{tabular}


Appendix. (Continued).

\begin{tabular}{|c|c|c|c|c|}
\hline $\begin{array}{c}\text { Sample } \\
\text { (level in cm) }\end{array}$ & $\begin{array}{l}\text { Sub-bottom } \\
\text { Depth } \\
\text { (m) }\end{array}$ & $\begin{array}{c}\text { Total } \\
\text { Carbon } \\
(\%)\end{array}$ & $\begin{array}{c}\text { Organic } \\
\text { Carbon } \\
(\%)\end{array}$ & $\begin{array}{c}\mathrm{CaCO}_{3} \\
(\%)\end{array}$ \\
\hline $27-2,30$ & 130.05 & 2.5 & 2.4 & 1 \\
\hline $27-2,60$ & 130.35 & 2.8 & 2.7 & 1 \\
\hline $27-2,90$ & 130.65 & 2.7 & 2.8 & 0 \\
\hline $27-2,110$ & 130.85 & 2.7 & 2.8 & 0 \\
\hline $27-2,130$ & 131.05 & 2.9 & 2.8 & 0 \\
\hline $27-3,0$ & 131.25 & 2.4 & 2.3 & 1 \\
\hline $27-3,30$ & 131.55 & 2.4 & 2.4 & 0 \\
\hline $27-3,60$ & 131.85 & 2.5 & 2.5 & 0 \\
\hline $27-3,80$ & 132.05 & 2.2 & 2.2 & 0 \\
\hline $27-3,100$ & 132.25 & 2.5 & 2.5 & 0 \\
\hline $27-3 ; 120$ & 132.45 & 2.7 & 2.7 & 0 \\
\hline $28-1,15$ & 133.15 & 2.3 & 2.2 & 1 \\
\hline $28-1,50$ & 133.50 & 2.2 & 2.2 & 0 \\
\hline $28-1,70$ & 133.70 & 2.5 & 2.4 & 0 \\
\hline $28-1,90$ & 133.90 & 2.5 & 2.3 & 1 \\
\hline $28-1,110$ & 134.10 & 3.0 & 2.4 & 5 \\
\hline $28-1,130$ & 134.30 & 2.6 & 2.4 & 2 \\
\hline $28-2,10$ & 134.60 & 2.6 & 2.4 & 2 \\
\hline $28-2,30$ & 134.80 & 2.3 & 2.3 & 0 \\
\hline $28-2,50$ & 135.00 & 2.4 & 2.4 & 0 \\
\hline $28-2,70$ & 135.20 & 2.4 & 2.3 & 0 \\
\hline $28-2,90$ & 135.40 & 2.7 & 2.5 & 1 \\
\hline $28-2,110$ & 135.60 & 2.6 & 2.5 & 0 \\
\hline $28-2,130$ & 135.80 & 3.0 & 2.5 & 4 \\
\hline $28-3,0$ & 136.00 & 2.8 & 2.7 & 1 \\
\hline $28-3,20$ & 136.20 & 2.8 & 2.8 & 1 \\
\hline $28-3,40$ & 136.40 & 2.9 & 2.8 & 1 \\
\hline $28-3,60$ & 136.60 & 2.8 & 2.6 & 1 \\
\hline $28-3,80$ & 136.80 & 3.2 & 3.1 & I \\
\hline $28-3,100$ & 137.00 & 3.9 & 3.0 & 7 \\
\hline $29-1,0$ & 137.75 & 4.0 & 2.9 & 9 \\
\hline $29-1,20$ & 137.95 & 3.5 & 2.9 & 5 \\
\hline $29-1,40$ & 138.15 & 3.3 & 3.0 & 2 \\
\hline $29-1,86$ & 138.61 & 2.7 & 2.7 & 0 \\
\hline $29-1,110$ & 138.85 & 2.7 & 2.6 & 1 \\
\hline $29-1,130$ & 139.05 & 2.5 & 2.3 & 1 \\
\hline $29-2,30$ & 139.55 & 2.1 & 2.0 & 1 \\
\hline $29-2,50$ & 139.75 & 2.5 & 2.4 & 1 \\
\hline $29-2,70$ & 139.95 & 2.7 & 2.6 & 1 \\
\hline
\end{tabular}

Appendix. (Continued).

\begin{tabular}{|c|c|c|c|c|}
\hline $\begin{array}{l}\text { Sample }^{\mathrm{a}} \\
\text { (level in cm) }\end{array}$ & $\begin{array}{l}\text { Sub-bottom } \\
\text { Depth } \\
\text { (m) }\end{array}$ & $\begin{array}{c}\text { Total } \\
\text { Carbon } \\
(\%)\end{array}$ & $\begin{array}{c}\text { Organic } \\
\text { Carbon } \\
(\%)\end{array}$ & $\begin{array}{c}\mathrm{CaCO}_{3} \\
(\%)\end{array}$ \\
\hline $29-2,90$ & 140.15 & 2.8 & 2.7 & 1 \\
\hline $29-2,110$ & 140.35 & 2.7 & 2.6 & 1 \\
\hline $29-2,130$ & 140.55 & 2.6 & 2.4 & 1 \\
\hline $29-3,0$ & 140.75 & 2.8 & 2.7 & 1 \\
\hline $29-3,20$ & 140.95 & 2.6 & 2.5 & 1 \\
\hline $29-3,40$ & 141.15 & 2.5 & 2.4 & 1 \\
\hline $29-3,60$ & 141.35 & 2.6 & 2.5 & 1 \\
\hline $29-3,85$ & 141.60 & 2.9 & 2.8 & 1 \\
\hline $29-3,110$ & 141.85 & 2.8 & 2.7 & 1 \\
\hline $29-3,130$ & 142.05 & 2.7 & 2.6 & 1 \\
\hline $30-1,70$ & 143.20 & 2.7 & 2.7 & 0 \\
\hline $30-1,110$ & 143.60 & 2.6 & 2.6 & 0 \\
\hline $30-1,140$ & 143.90 & 2.5 & 2.4 & 1 \\
\hline $30-2,20$ & 144.20 & 2.5 & 2.5 & 0 \\
\hline $31-1,30$ & 147.55 & 2.5 & 2.4 & 0 \\
\hline $31-1,50$ & 147.75 & 2.3 & 2.2 & 1 \\
\hline $31-1,70$ & 147.95 & 2.3 & 2.3 & 0 \\
\hline $31-1,80$ & 148.05 & 2.4 & 2.2 & 2 \\
\hline $31-1,90$ & 148.15 & 1.9 & 1.8 & 1 \\
\hline $31-1,110$ & 148.35 & 2.4 & 2.3 & 1 \\
\hline $31-1,110$ & 148.35 & 2.4 & 2.3 & 1 \\
\hline $31-1,130$ & 148.55 & 2.6 & 2.4 & 1 \\
\hline $31-2,0$ & 148.75 & 2.5 & 2.5 & 0 \\
\hline $31-2,20$ & 148.95 & 2.5 & 2.4 & 1 \\
\hline $31-2,40$ & 149.15 & 2.4 & 2.2 & 2 \\
\hline $31-2,60$ & 149.35 & 2.9 & 2.4 & 4 \\
\hline $31-2,80$ & 149.55 & 3.3 & 2.4 & 7 \\
\hline $31-2,100$ & 149.75 & 2.3 & 2.2 & 0 \\
\hline $31-2,120$ & 149.95 & 2.4 & 2.2 & 1 \\
\hline $31-2,140$ & 150.15 & 2.4 & 2.4 & 0 \\
\hline $31-3,15$ & 150.40 & 2.6 & 2.5 & 1 \\
\hline $31-3,40$ & 150.65 & 2.6 & 2.4 & 2 \\
\hline $31-3,60$ & 150.85 & 2.5 & 2.4 & 1 \\
\hline $31-3,80$ & 151.05 & 2.4 & 2.2 & 2 \\
\hline $31-3,110$ & 151.35 & 2.4 & 2.3 & 1 \\
\hline
\end{tabular}

a Interval and depth figures refer to the top of a $10-\mathrm{cm}$ integrated sample interval, with some $20-\mathrm{cm}$ intervals sampled in homogeneous zones. 